\title{
Modelling wetland connectivity during overbank flooding in a tropical floodplain in north Queensland, Australia
}

Fazlul Karim*,a, Anne Kinsey-Henderson ${ }^{\mathrm{a}}$, Jim Wallace ${ }^{\mathrm{a}}$, Angela H. Arthington ${ }^{\mathrm{b}}$ and Richard G. Pearson ${ }^{\mathrm{c}}$

${ }^{\mathrm{a} C S I R O ~ L a n d ~ a n d ~ W a t e r, ~ A T S I P, ~ T o w n s v i l l e, ~ Q u e e n s l a n d ~ 4814, ~ A u s t r a l i a ~}$

${ }^{\mathrm{b}}$ Australian Rivers Institute, Griffith University, Nathan, Queensland 4111, Australia

${ }^{\mathrm{c}}$ School of Marine and tropical Biology, James Cook University, Queensland 4814, Australia

*Correspondence to: Fazlul Karim, ${ }^{\mathrm{a} C S I R O}$ Land and Water, Davies Laboratory, Townsville, Queensland 4814, Australia

Phone: +61747538580

Fax: +61 747538600

E-mail: Fazlul.Karim@csiro.au

Short Title: Hydrological connectivity of floodplain wetlands

KEY WORDS: wetlands, hydrological connectivity, hydrodynamic modelling, floodplain, aquatic biota 


\begin{abstract}
Hydrological connectivity between floodplain wetlands and rivers is one of the principal driving mechanisms for the diversity, productivity and interactions of the major biota in riverfloodplain systems. This paper describes a method of quantifying flood-induced overbank connectivity using a hydrodynamic model (MIKE 21) to calculate the timing, duration and spatial extent of the connections between a number of floodplain wetlands and rivers in the Tully-Murray catchment, north Queensland, Australia. Areal photogrammetry and field surveyed stream-cross data were used to reproduce floodplain topography and rivers in the model. Laser altimetry (LiDAR) derived fine resolution elevation data, for the central floodplain, were added to the topography model to improve the resolution of key features including wetlands, flow pathways and natural and artificial flow barriers. The hydrodynamic model was calibrated using a combination of in-stream and floodplain gauge records. A range of off-stream wetlands including natural and artificial, small and large were investigated for their connectivity with two main rivers (Tully and Murray) flowing over the floodplain for flood events of 1,20 and 50 year recurrence intervals. The duration of connection of individual wetlands varied from 1 to 12 days, depending on flood magnitude and location in the floodplain, with some wetlands only connected during large floods. All of the wetlands studied were connected to the Tully River for shorter periods than they were to the Murray River, due to the higher bank heights and levees on the Tully River and wetland proximity to the Murray River. Other than hydrology, land relief, river bank elevation and levee banks along the river were found key factors controlling the degree of connectivity. These variations in wetland connectivity could have important implications for aquatic biota that move between rivers and off-stream habitats during floods.
\end{abstract}




\section{INTRODUCTION}

Floodplains have unique and important ecosystem functions in riverine landscapes. They frequently function as hot spots of biodiversity owing to complex patterns of habitat variation over a wide range of temporal and spatial scales (Swales et al., 1999; Tockner et al., 2010). Habitat quality, biodiversity and the ecological integrity of floodplain wetlands depends on many factors, but a key determinant is how the wetland is hydrologically connected to the main river channel over time (Junk et al., 1989; Paterson and Whitfield, 2000; Tockner et al., 2000; Pringle, 2001; Frazier and Page, 2006; Balcombe and Arthington 2009). In a wet tropical region, permanent flows often provide continuous in-stream connectivity; however, off-stream wetlands may be isolated for significant periods when low flows are constrained to the main stream channels. Flood flows provide opportunities for these off-stream wetlands to be connected with the main channels of floodplain river systems and these 'flood pulses' are thought to be the driving force for the high biodiversity of floodplain by creating heterogeneity of habitats (Gopal and Junk, 2000). During floods there is an exchange of water, sediments, chemicals, organic matter and biota between the main channels and floodplain wetlands (Junk et al., 1989; Thoms, 2003; Bunn et al., 2006; Tockner et al., 2010). Since publication of the Flood Pulse Concept (Junk et al., 1989), the importance of overbank flow connection for these exchanges and the productivity of diverse aquatic biota in riverfloodplain systems has been emphasized in many studies (e.g. Bayley, 1991; Heiler et al., 1995; Middleton, 2002; Welcomme et al., 2006; Gallardo et al., 2009). For example, the single most important factor for the persistence of the fish assemblage in an isolated wetland is the flow connection between the wetland and a main stream (Lasne et al., 2007; Leigh et al., 2010; Arthington and Balcombe, 2011). Furthermore, a high connectivity level is needed to conserve native fish diversity because the number of protected and native species increases with connectivity and the number of alien species and individuals can increase with isolation (Bunn and Arthington, 2002; Lasne et al., 2007). Yet our knowledge of the hydrological connectivity and ecological functioning of many of the world largest floodplain systems is very limited and insufficient to inform water management and biodiversity protection, or adaptation to future climate change (Sparks, 1995).

Despite centuries of human activities in altering the river-floodplain, remnant wetlands still exist, but they are diminishing at increasing rates (Bayley, 1995; Sparks, 1995; Tockner et al., 2008). An important issue for the management of the existing wetlands under present and 
future climate is to know the extent, timing and duration of their connectivity in order to derive ways to maintain or even enhance an optimal level of connection and biophysical exchanges between off-stream wetlands and a main channel or several channels. However, accurate information on wetland connectivity is scarce since field based monitoring of connectivity for numerous individual wetlands is both difficult and time consuming (Rosenfield and Hatfield, 2006). A number of studies have used a combination of remotely sensed inundated area and concurrent river flow to predict how flooded area changes with river flow (e.g. Townsend and Walsh, 1998; Hess et al., 2003; Overton, 2005; Frazier et al., 2006; Peake et al., 2011). The same approach has also been used to quantify how the number of inundated wetlands changes with river flow (Shaikh et al., 2001; Frazier et al., 2003; Ganf et al., 2010). However, this approach is not dynamic and only gives information on potential wetland inundation when flow is not changing rapidly (due to the time difference between when the remote sensing images can be obtained and the peak of inundation) and it is not possible to define the duration of wetland connectivity, which can have an important influence on wetland ecology. With the development of computational methods and computer technology hydrodynamic modelling has become popular for the study of floodplain hydraulics and quantifying the time course of flood inundation with high spatial and time resolution (Nicholas and Mitchell, 2003; Stelling and Verwey, 2005; Schumann et al., 2009). By combing this modelling technique with high resolution topography, the duration, frequency and timing of wetland connectivity can be quantified (Karim et al., 2011). Previous studies of this type have used a combination of hydrologic and hydrodynamic models of simplified one-dimensional (e.g. Beighley et al., 2009; Chormanski et al., 2009; Ganf et al., 2010; Rebecca et al., 2011) to more complex two-dimensional (Tuteja and Shaikh, 2009) modelling. However, these studies have limited use for calculating wetland connectivity since they focused on basin scale inundation and did not differentiate overbank connectivity from channelized connectivity. In this study we have used a two-dimensional model to simulate the time history of inundation across a tropical floodplain. An algorithm was then developed to combine the hydrodynamic results with a topography model to quantify overbank connectivity of different wetlands. Results of our hydrological connectivity analyses are presented here and the ecological roles of connectivity and habitat diversity in the floodplain wetlands will be presented elsewhere. 


\section{MATERIAL AND METHODS}

\section{Study Site}

The study focused on the freshwater wetlands in the Tully-Murray catchment located in the southern part of the Wet Tropics bioregion on the north-east coast of Australia (Figure 1). This relatively small catchment adjacent to the Great Barrier Reef (GBR) lagoon covers an area $2072 \mathrm{~km}^{2}$, of which $832 \mathrm{~km}^{2}$ is floodplain (Karim et al., 2008). Topography varies from steep rainforest covered mountains in the upper catchment, to the low relief floodplain containing agriculture (mainly sugarcane, grazing and bananas) in the lower catchment. The ecosystems of this region provides a range of habitats for rare and threatened flora and fauna (Sattler and Williams, 1999). However, habitats throughout the Tully-Murray floodplain are highly fragmented and this has considerable effects on the sustainability of various fauna and flora populations (Burrows, 1999).

Mean annual rainfall across the catchment varies in the range of 2000 to $4000 \mathrm{~mm}$, depending on the location in the catchment. Most of the rainfall (60-80\%) occurs during the wet season from December to April. The Tully and Murray Rivers are the two main waterways that receive catchment runoff through numerous creeks and they both discharge into the GBR lagoon. Flooding is common on the floodplain, with the rivers going overbank 3 to 4 times a year during the wet season (Wallace et al., 2008). The mean annual flood has a discharge around twice the bankfull discharge. Since the topography of the Tully-Murray floodplain is very flat and rivers are quite close, water from the two rivers often merges during a flood. The combined river inundation area connects a number of wetlands depending on the flood magnitude.

The wetlands of tropical Australia are considered very significant from an environmental perspective as they provide habitat for aquatic and riparian biota in addition to potentially improving water quality delivered to the GBR lagoon (Johnson et al., 1997). They constitute a substantial proportion of the remnants of a large number of similar habitats that existed in the Wet Tropics prior to agricultural development, which has led to as much as $75 \%$ of these wetlands being drained and filled (Johnson et al., 1997; EPA, 1999). The main wetlands are complemented by a network of smaller natural and artificial wetlands, some of which have been developed primarily to reduce the impacts of adjacent farming by acting as sediment and nutrient sinks, flood detention basins or both (Veitch and Sawynok, 2004). Some wetlands are 
connected directly to the rivers, but the majority are connected to the rivers indirectly through a creek or a cane drain or a combination of both. Ephemeral wetlands are located relatively distant from the main streams and have less stream connection with the rivers. However, these wetlands become connected to the rivers during floods. The Tully-Murray floodplain supports a range of wetlands, varying in size, bathymetry, surrounding vegetation and water quality, producing clear biophysical gradients in a number of parameters. However, these gradients were not extreme as there were apparently no pristine sites and none that were severely degraded from water quality perspective, probably because of the regular flushing of lagoons resulting from the rainfall regime of the region (Pearson et al., 2010). Wetlands in the TullyMurray catchment are reported as among the highest value in the GBR catchment from a fishery perspective (Veitch and Sawynok, 2004). The wetlands studied were largely palustrine (shallow vegetated) lagoons and are located between the Tully and Murray Rivers.

\section{Data Collection and Analysis}

\section{Rainfall and stream flow}

Daily rainfall data were obtained from the Australian Bureau of Meteorology (BOM) for the period of 1980 to 2009. Data records for this catchment are fairly good and there are a total 17 rain gauges across the catchments with an average distance of $9.2 \mathrm{~km}$ between gauges. Considering proximity among the stations and data quality, records from 11 rain gauges (see Figure 1 for location) were used to estimate mean areal rainfall using the Thiessen-polygon method (Subramanya, 1994) to delineate areas of equal rainfall. As rainfall varies across the catchment we estimated the mean rainfall $\left(P_{\text {mean }}\right)$ over any area $\left(A_{i}\right)$ as;

$$
P_{\text {mean }}=\sum_{i=1}^{M} P_{i} \frac{A_{i}}{A}
$$

where $M$ is the number of rainfall zones, $A$ is the total area and $P_{i}$ is the rainfall recorded in area $A_{i}$.

\section{Stream flow}

Gauged data were used to specify model boundaries and to calibrate the rainfall-runoff and hydrodynamic models. Mean daily discharge and stage height data for the period of 1980 to 2009 were obtained from the Department of Environment and Resource Management (DERM), Queensland Government. The Tully River is relatively long (130 km) and there are two gauges in the upper-catchment and one gauge in the floodplain, The Murray River is relatively short $(70 \mathrm{~km})$ and there are one gauge in the upper catchment and one gauge in the 
floodplain. Stream gauges at Ebony Road and Powerline (Figure 1) record sub-catchment runoff in the Tully catchment and the Upper Murray gauge records sub-catchment runoff in the Murray catchment. Data from these 3 gauges were used to calibrate a rainfall-runoff model. The gauges at Euramo on the Tully River and Murray Flats on the Murray River (Figure 1) are located in the floodplain and stage height data from these two gauges were used to calibrate the floodplain hydrodynamic model.

\section{Topography}

The topography of the study area used in the hydrodynamic model was a $30 \mathrm{~m}$ grid digital elevation model (DEM). This DEM was primarily based on areal photogrammetry data derived by Connell Wagner (2006) giving one coarse resolution ( $\pm 0.7 \mathrm{~m}$ vertical accuracy) data set for the entire floodplain area and one fine resolution $( \pm 0.15 \mathrm{~m}$ vertical accuracy $)$ data set along the main highway and railway. The bathymetry of the Tully and Murray Rivers and major creeks was added to the DEM using surveyed cross-sections. As creek widths are relatively small (10 to $70 \mathrm{~m}$ ) and at many locations less than the grid size, the creek width was adjusted to ensure a continuous creek section until it met with a river or another creek. Fine scale details for the main wetlands in the floodplain were embedded into the $30 \mathrm{~m}$ DEM using re-sampled $3 \mathrm{~m} \mathrm{LiDAR}$ data. Bathymetry of the wetlands was estimated using a combination of LiDAR data (i.e. above their end of dry season water level) and field surveys of the submerged bathymetry. Wetlands were reproduced in the model using a set of rectangular grids ensuring the surface area was kept as close as possible to the actual wetland area.

\section{Roughness}

We used Manning's roughness coefficients $n$ to represent land surface resistance to the propagating flood wave. A surface roughness map was developed for the hydrodynamic domain with the same size grid as the hydrodynamic model using the Queensland land use map (Pitt et al., 2007). Initial roughness coefficients were estimated based on land use following Connell Wagner (2006) and then refined as a part of the model calibration process. Land use in the Tully-Murray floodplain is dominated by sugarcane plantations, interspersed with some grazing land. The next largest land use is banana farming, which is concentrated in the upstream reaches of the Tully floodplain (Armour et al., 2007). To produce a hydraulic roughness map, vegetation covers were classified as sugar cane, banana, grazing, cereal and urban. The water bodies were categorised as wetlands, creeks, and rivers. Sugarcane roughness is very dependent on the cane growth stage at the time of flooding (i.e. a fallow 
field can create a flow path while a fully mature cane field can act as a strong impediment to flow). River flow records show that most of the overbank events occur between January and March (Wallace et al., 2008), when cane fields are generally fully covered by plants, so a high roughness value was adopted for cane areas.

\section{Model Setup and Calibration}

\section{Model configuration}

Propagation of the flood wave across the floodplain and associated inundation levels were simulated using the MIKE 21 hydrodynamic model, a fully dynamic two-dimensional flow model (DHI, 2008a). The model is based on the depth-averaged Saint-Venant equations describing the evolution of water levels, and two Cartesian velocity components (Garcia and Kahawita, 1986). Governing flow equations were solved by an implicit finite difference scheme with the variables defined on a space-staggered rectangular grid. An alternating direction implicit (ADI) algorithm was used to calculate variables at each time step. The governing equations and details of the solution techniques are available in Rungo and Olesen (2003). The solution results in grid-based water levels and velocities in the two horizontal directions ( $x$ and $y$ ) over the entire computational period.

The computational domain was $720 \mathrm{~km}^{2}(30 \mathrm{~km} \times 24 \mathrm{~km})$ covering the entire floodplain (Figure 1), which is $32 \%$ of the total catchment area. Inputs to the model were land elevation, surface roughness and water sources. Model boundaries include inflows through the Tully and Murray Rivers, and through 4 creeks. At the downstream, seaward boundary water levels equal to the Mean High Water Spring (MHWS) tide were used. The downstream boundaries were set sufficiently distant from the floodplain so that boundary effects (if any) were insignificant on floodplain flows.

\section{Flow conditions}

There are two sources of water that cause the flood pulse on the Tully-Murray floodplain. The main source is the stream flow through the Tully and Murray Rivers which originates in the upper parts of the catchments. The other source of water is the rainfall-generated runoff within the floodplain. Runoff for storm events was simulated using the NAM rainfall-runoff model (DHI, 2008b) which is a physically based lumped hydrological model. The model is based on a set of linked mathematical equations that represent various components of the 
rainfall-runoff process by continuously accounting for water content in different but mutually linked stores. The model computes runoff using 9 parameters that govern surface runoff, subsurface runoff and base flow (see Table I). Initial model parameters were estimated based on soil properties (Cannon et al., 1992) and land uses (Armour et al., 2007). Final parameters were obtained by a calibration process. Runoff peaks and low flows, timing of peaks and low flows, and total volume of runoff were the key variables considered during calibration.

The Tully and Murray catchments were divided into a number of sub-catchments based on land topography. Sub-catchment boundaries and stream networks were generated using ArcGIS Hydro Tools (Smith and Brough, 2006). The area above the hydrodynamic model domain was divided into 15 sub-catchments with an average area of $96 \mathrm{~km}^{2}$, based on stream networks that carry upper catchment runoff to the floodplain. The Tully and Murray Rivers and 4 small creeks carry runoff from these catchments into the floodplain. Flows from these sub-catchments were specified as inflow sources at a point of intersection between a stream and the hydrodynamic model boundary. Runoff for individual sub-catchments was estimated separately and then propagated through sub-catchments further downstream. Routing of runoff water between individual sub-catchments to the hydrodynamic model boundary was done using the MIKE 11 model (DHI, 2008c).

Runoff within the hydrodynamic domain was simulated using much smaller sub-catchments with an average area of $9.7 \mathrm{~km}^{2}$. Sub-catchment boundaries and location of their outlets were obtained from previous hydrodynamic modelling studies by Connell Wagner (2006). A total of 66 sub-catchments, 19 linked with the Tully River and 47 linked with the Murray River, were used in the floodplain. Runoff was estimated using the NAM model described above and modelled runoff (time varying flow rates) were added to the hydrodynamic model as a point source at the outlet of each sub-catchment.

\section{Flood simulation}

The hydrodynamic model domain was divided into 800,000 computational grids each $30 \mathrm{~m}$ by $30 \mathrm{~m}$ in space. Computational time increment was derived after satisfying numerical stability criteria. A time step of $4 \mathrm{sec}$ was used as this produced a stable solution for floods with an average recurrence interval (ARI) of up to 50 years. Simulation of each flood event was carried out for 12 days to include the full flooding period of the largest flood. Computed timevarying water depths were recorded hourly at some selected points and two-hourly for all 
computational points. These data were then used to calculate extent of flooding and inundation depth across the floodplain.

Flood scenarios were investigated for 3 storm events of different size with ARIs of 1, 20 and 50 years. Design rainfalls for these storm events were estimated using rainfall frequency analyses for the Tully area by BMT WBM (2008). These estimates were based on the CRCFORGE method (Durrant and Bowman, 2004), which is a regional analytical method for developing point rainfall at different risk levels from data records of a relatively short period. Predicted rainfall magnitudes for 1, 20 and 50 ARI storm events were 408, 672 and $813 \mathrm{~mm}$ respectively. These results represent averaged rainfall over the catchment without consideration of spatial variation. Temporal distributions of rainfall for these events were obtained using 4-hourly temporal pattern hyetographs from the Institution of Engineers Australia (IEA) derived by Pilgrim et al. (2001). The critical storm duration for floods in the Tully-Murray floodplain is 72 hours (BMT WBM, 2008). Combining this with temporal patterns hyetographs gave rainfall distributions for 72-hour storms that were divided into 18 periods each of 4 hours duration. Floodplain runoff was then simulated using the previously calibrated NAM runoff model.

\section{Model calibration}

In the NAM model calibration process, parameters were adjusted iteratively to obtain reasonable agreement between measured and simulated runoff volumes, peaks and low flows. Sensitivity of each parameter was investigated and parameters influencing the runoff volume and timing of peaks and lows were indentified. The parameters were calibrated for two subcatchments, one for the Cochable Creek sub-catchment at upper Tully and one for the Upper Murray sub-catchment in the Murray catchment (Figure 1). As shown in Table I, calibrated parameters for these two sub-catchments differ considerably as they are sensitive to both catchment physical properties and the hydrological behaviour of the catchment. Calibrated parameters were kept unchanged in the subsequent simulations. Figure 2 shows a comparison between simulated and observed runoff at Powerline for the Coachable Creek sub-catchment which is located in the upper Tully catchment (Figure 1). The results show good agreement between simulated and observed flow rates throughout the hydrograph (Figure 2a). Simulated accumulated flow is also very close to the observed accumulated flow (Figure 2b). The differences between simulated and observed mean and peak discharges were only $0.5 \%$ and $1.6 \%$, respectively. The results were evaluated in terms of commonly used statistical 
parameters, namely root mean square error, correlation coefficient and relative error. Computed statistical parameters for 2 sets of gauge data at Powerline and at Upper Murray are given in Table II.

The hydrodynamic model was calibrated for the mean annual flood using an actual flood event in 2007 (19 February to 1 March), which had an ARI of 1 year. During the calibration process, floodplain topography was slightly modified at a few locations to rectify model instability due to very high velocities that occurred at sharp gradients. Surface roughness coefficients (Manning's $n$ ) were varied iteratively for the major land uses (sugarcane, banana, grazing and urban) within the recommended range to attain close agreement between measured and simulated water heights in the river and on the floodplain. Roughness coefficients for water bodies were estimated using the guidelines given by Chow (1959) and were held constant during calibration. A brief summary of the calibrated roughness coefficients is given in Table III. The calibrated $n$ value for sugarcane is 0.20 which is the maximum among the land uses followed by urban areas $(n=0.12)$ and banana fields $(n=$ $0.10)$. We used a relatively large $n$ for wetlands as in the Tully-Murray floodplain they are surrounded by tall grasses and small to large trees. A comparison of water level hydrographs at Euramo is shown in Figure 3a. The overall agreement between measured and simulated water heights is good and the differences are within $\pm 0.2 \mathrm{~m}$ for the first peak and $\pm 0.5 \mathrm{~m}$ for the second peak. Figure $3 \mathrm{~b}$ shows an independent comparison of stage height for another flood event (with an ARI of 1.9 year) for the same set of model parameters. It can be seen that the simulated peak is the same as the measured peak, but there are some discrepancies in the falling limb of the flood hydrograph. However, this comparison shows that the calibrated hydrodynamic model can be used for floods other than the calibration event.

\section{Connectivity Assessment}

\section{Wetland selection}

Under the strategy for the conservation and management of wetlands in Queensland the Environmental Protection Agency (EPA) has documented detailed wetland information including type, size and location for selected regions of the state (EPA, 2005). However, the EPA wetland maps only provide information for wetlands that are larger than 1 ha. To identify wetlands in the Tully-Murray floodplain and their links with the stream network, a LiDAR survey was conducted in October 2007 for the area between the Tully and Murray 
Rivers and a 3-m grid DEM was produced. Wetlands in the surveyed area were identified from this high resolution DEM. Ten wetlands (ranging in size from 0.5 to 6.0 ha) were then selected for connectivity assessment based on their perceived importance for aquatic biota (e.g. type, size and location). The key information on type (artificial or natural), location and areal extent of the wetlands studied are shown in Figure 4. The Kyambul is the only riverine wetland and the rest are palustrine.

\section{Method of analysis}

Connectivity during floods is defined as overbank flow connection between a wetland and the main stream of flow. Connection and disconnection during over bank flooding were identified using a threshold water depth. We first simulated spatial and temporal water depths using the hydrodynamic model. This gave a time series of water depths at each wetland and along the intervening overbank pathways, from which the timing and duration of connection with surrounding water bodies and/or with main streams were estimated. A wetland was considered connected by the flood pulse with other water bodies when it started receiving water from other sources by overbank flow, and was considered disconnected when water receded below its bank level. This definition of connectivity is graphically illustrated in Figure 5 using a hypothetical water depth at a wetland. In this figure, $\mathrm{t}_{1}$ represents the start and $t_{2}$ the end of hydrologic connection, while the difference between $t_{2}$ and $t_{1}$ is the duration of connection. Connection time and duration of connection are different for floods of different magnitudes. In general, large flood events produce earlier and longer durations of connection. The estimation of connection time of a particular wetland to the river system was based on time series water depths derived from the hydrodynamic model at 2-hourly time steps. To do this, an algorithm was developed to uniquely identify areas of contiguous water during each time step, by tagging all water bodies and river sections which were contiguous in that time step. The same procedures were repeated for all time steps and the results were accumulated to obtain the temporal sequence of connection and disconnection.

\section{RESULTS}

\section{Floodplain Inundation}

\section{Areal extent}

The maximum extent of floodplain and wetland inundation for the floods with ARIs of 1,20 and 50 years is shown in Figure 6. A large part of the area between the Tully and Murray 
Rivers is inundated for a 1 year ARI flood and nearly all areas between the rivers are inundated for a 20 ARI flood. All wetlands except Lagoon Creek are inundated for a 1 ARI flood. Inundation areas are summarised in Table IV and compared between flood events. Relatively frequent floods (ARI = 1 year) inundate over a third of the floodplain and this increases to just over half of the floodplain with larger floods (ARI $=20$ years). There is not much increase in inundated area with further increase in flood magnitude (ARI $=50$ years) because these rarer events add relatively small amount of additional water into parts of the floodplain with a steeper slope, since most of the low-lying lands are already inundated by a 20 year ARI flood.

\section{Duration of inundation}

Another important aspect of floods on wetland habitats is the duration of inundation, which increases with flood size. We used 2-hourly flood depth information derived from the MIKE 21 hydrodynamic model to estimate the duration of inundation at each model grid for the entire period of simulation. A typical example of inundation duration at different parts of the floodplain is shown in Figure 7. It can be seen that areas surrounding the wetlands flooded for relatively longer duration. Also areas adjacent to the Murray River flooded for longer durations than areas adjacent to the Tully River.

\section{Seasonality of inundation}

The timing of flood events is also important to wetland biota and we therefore examined seasonal variations of flood timing in these catchments using 38 years of recorded flood data. The results of this analysis show flooding is generally confined to the wet season with the largest flood flows occurring in January (Figure $8 \mathrm{a}$ ), when several $\mathrm{km}^{3}$ of water can inundate the floodplain (Wallace et al., 2009). However, floods have been recorded as early as 11 December and as late as 20 June. In contrast to flood volume, the number of floods reaches a maximum later in the year between February and March (Figure 8b), coincident with the maximum monthly rainfall. During these months, flooding occurs almost every year (on average), whereas the flood frequency is about half of this in January and April (i.e. 1 in 2 years) and much rarer in December ( 1 in 8 years), May (1 in 13 years) and June (1 in 38 years). For the entire wet season flooding can occur up to 10 times, but on average there are 3 to 4 overbank floods per year. 
The first flood of any wet season may be particularly important to aquatic biota, so these floods were analysed separately. On average, first floods were not any different in size from other floods and they tended to occur earlier in the year, around January. Individual flood durations ranged from 1 to 13 days, with the longer duration associated with the larger floods. For the entire wet season the floodplain can be inundated for up to 34 days; however, there is an average of 12 days each year when freshwater biota can exploit the wetland connections associated with floodplain inundation.

\section{Wetland Connectivity}

An analysis of overbank connectivity between a wetland (e.g. Bunta) and surrounding water bodies is shown in Figure 9 for two flood events of ARIs 1 and 20 years. A sharp rise in water depth signals the start of flow connection with other water bodies. It can be seen that initial connection for a 20 year ARI flood occurred earlier than with a 1 year ARI flood. This is because the larger flood produced a higher velocity and hence faster moving flood wave. The duration of connection with surrounding water bodies is longer for the larger flood as the greater amount of flood water takes longer to drain from the floodplain.

Connectivity of wetlands to the Tully and Murray Rivers was computed by identifying contiguous flow paths at every 2-hour time step. To do this a threshold water depth needs to be chosen to ensure continuous water connection across minor topographic variations in the landscape and because we are interested in wetland connectivity that may allow movement of fish (McGuckin, 2000; Bunn and Arthington, 2002), which can be impeded at low water depths (Sanger, 2000). We chose a threshold depth of $30 \mathrm{~cm}$ to distinguish between connected and disconnected water bodies. Figure 10 shows an example of this type of connectivity analysis for a single time step 106 hours into a flood with an ARI of 1 year. Different interconnected regions for this particular time are shown on this figure. For example, in the $5^{\text {th }}$ day after the start of the 1 year ARI flood, the wetlands within region 1 were connected with each other and with the Murray River, but not connected with the Tully River. At the same time wetlands in region 2 were connected with neither river. By checking contiguous water at every time step and accumulating this information for the entire flood period, the duration of connectivity of each wetland with the two rivers was obtained. Summaries of connection timing and duration of connection of the wetlands to the Tully and Murray Rivers are shown in Figure 11 for the flood events of February 2007 which is equivalent to 1 year return period flood. It can be seen that Lagoon Creek was not connected to either river. This is because 
Lagoon Creek is relatively elevated and flood water only reaches it during larger floods. It can be seen that duration of connection of wetlands to the Murray River is longer than to the Tully River. It is important to note that flood events with a second, but smaller peak (e.g. Figure 3a) may reconnect some of wetlands that are disconnected after the first peak recedes (e.g. see Selby's wetland during the 1 year ARI flood, Figure 11).

As indicated previously, larger floods produce longer durations of flooding and they also create longer durations of connectivity. A comparison of the duration of connectivity for 20 and 50 years return period floods are shown in Figure 12. It can be seen that flood magnitude has less influence on initial connection, but larger floods produce much longer connectivity with the rivers for the majority of wetlands. Figure 12 also shows that Lagoon Creek wetland, which was not connected with the rivers for one 1 year return period flood, was connected to both rivers for floods of 20 to 50 years ARI. The duration of connectivity for all 10 wetlands for each of the 3 different floods are summarised in Table V. For the majority of the wetlands the duration of connectivity ranges from 1 to 4 days with the Tully River as flood size increases. Connectivity is much longer to the Murray River; 2 to 12 days as flood size increases. Connectivity with the Tully River does not greatly increase as flood size increases from an ARI of 20 to 50 year, whereas connectivity of some of the wetlands with the Murray River increases quite markedly.

\section{DISCUSSION}

\section{Assessing Inundation}

The magnitude of floods is seen as a primary factor for the extent of floodplain inundation. However, as seen in Figure 6, the rate of increase in inundation is not linear with increased flood magnitude. For example, a 50 year flood which is $19 \%$ larger in terms of maximum discharge and $21 \%$ larger in terms of rainfall compared with a 20 year flood produced only $6 \%$ more inundation. This result is different from that found in other Australian floodplain inundation studies reported by Tuteja and Shaikh, (2009) where they found a significant increase in inundation area with increased river flow. However, the results for the TullyMurray are not surprising since it is high rainfall catchment having a relatively small floodplain surrounded by steep topography. This means that a large part of the floodplain is inundated during a relatively frequent flood (e.g. 1 ARI). Rarer events add relatively small 
amount of additional water into parts of the floodplain with a steeper slope, since most of the low-lying land is already inundated by the smaller flood.

Floodplain topography was also found to be a key factor influencing the duration of inundation across the floodplain. For example, the longer durations of flooding adjacent to the Murray River were primarily due to the low bank height of the Murray River and lower land elevation near this river (up to $4 \mathrm{~m}$ lower than the equivalent areas adjacent to the Tully River).

Flood magnitude was found to have relatively little impact on the number of wetlands inundated with only 1 wetland requiring a flood with an ARI $>1$ for this particular floodplain setting. This is because most of the wetlands in the Tully-Murray catchment are located in the relatively small area between the Tully and Murray Rivers, major parts of which are frequently inundated. This is quite different from a large floodplain where the number of wetlands inundated is highly dependent on flood size (e.g. see Overton, 2005; Gant et al., 2010).

\section{Assessing Connectivity}

The main focus of this study was to estimate wetland connectivity during floods for fish movement and our results are dependent on the threshold water depth used to distinguish between connected and disconnected water bodies. There is no single critical depth for fish movement because different fish species (and/or size) need different water depths to move across the floodplain. This floodplain is dominated by agricultural land with significant soil microtopography and dense vegetation cover which could obstruct fish movement during relatively shallow floods. We therefore used a relatively high threshold depth $(30 \mathrm{~cm})$ to quantify fully connected water bodies from rest of the floodplain, however, the validity of this choice of depth threshold should be tested in future studies.

It is interesting to note that nearly all of the wetlands connect and disconnect with the Tully River at the same time. This is because the connection and disconnection of the largest body of flood water to the Tully River is via a single drainage line situated well upstream in this catchment (see Figure 7). Sedimentation and constructed levees along the Tully River contribute to this connectivity behaviour. Similar results are reported in Frazier and Page (2006) where they found about $40 \%$ reduction in wetland inundation due to river bank 
modification. In contrast, the Murray River which is a much less constrained river provides better connectivity to wetlands on the floodplain. This implies that any river bank modification introduced to reduce flooding could have the negative effect of reducing wetland connectivity with the main streams. In the relatively unmodified Murray River all wetlands (other than Lagoon Creek) were connected to the Murray River at more or less at the same. The main reason for this behaviour is the high flow velocity of the propagating flood wave and the proximity of most of the wetlands to this river. This connectivity behaviour is more typical of unmodified river-floodplain systems.

\section{Implication for Fish Ecology}

The major advantage of hydrodynamic modelling over GIS based models (e.g. Townsend and Walsh, 1998; Frazier et al., 2003) is its ability to predict detail of local variations in inundation timing and duration. This information is important for estimating fish response and recruitment in floodplain wetlands (Winemiller 1996; Pearson et al., 2010). It has also been reported by Swales et al. (1999) that floodplain inundation helps recovery of fish populations that become overstressed due to drought and algal blooms. Variations in wetland connectivity may therefore have important implications for wetland health and movement and recruitment patterns of aquatic biota during and after floods. For example, Pearson et al. (2010) studied fish assemblages in wetlands of the Tully-Murray floodplain and concluded that hydrological connectivity is a major factor that contributes to the differences in fish recruitment amongst the wetlands. Similar results have also been reported by Leigh and Sheldon (2009), where they found major influences of variation in hydrological connectivity on macroinvertebrate assemblages in a tropical floodplain. Hydrological connectivity also helps explain variations in wetland habitat quality and the biodiversity of individual wetlands.

\section{CONCLUSIONS}

This study has demonstrated how hydrological connectivity of floodplain wetlands can be quantified using hydrological and hydrodynamic modelling. This novel method can predict the extent, timing and duration of connectivity of a large number of wetlands of different types under a range of flood sizes. The method could also be used to estimate the effects of land modifications (e.g. the addition and or removal of levees or cane drains) or the potential impacts of climate change on wetland connectivity. The model also offers the potential to 
predict the ecological implications of various scenarios of floodplain hydrological alteration on fish assemblages and recruitment patterns in wetlands.

In high rainfall areas most of the wetlands within small floodplains surrounded by relatively steep topography are likely to regularly inundated (several times a year). Larger (and rarer) floods only marginally increase the number of wetlands inundated, but they do increase the duration of inundation and hence connection with the main river channels. Wetland connectivity with the rivers may continue well after the flood pulse recedes via the floodplain stream and drainage network. This form of connectivity has also been studied in the TullyMurray catchments and will be reported in a subsequent paper.

Finally, this study provides a good demonstration of how measures to reduce flooding using levee banks (e.g. in the Tully River) can change the timing and duration of wetland connectivity to the river. These variations in wetland connectivity may have important implications for (i) the movement and recruitment patterns of aquatic biota during and after flood events, (ii) wetland habitat characteristics and water quality, (iii) the biodiversity of individual wetlands over time, and (iv) the potential for wetland processes to influence the quality of water flowing to the Great Barrier Reef lagoon.

\section{ACKNOWLEDGMENTS}

We would like to thank the Australian Government Department of the Environment and Water Resources, Heritage and the Arts (DEWHA) and the Reef and Rainforest Research Centre's Marine and Tropical Science Research facility (MTSRF) for co-funding support for this study. We are grateful for the collaborative input of the Danish Hydrological Institute (DHI) and their provision of the software licenses for the 'MIKE 11' and 'MIKE 21' software. We would also like to thank the Queensland Department of Main Roads for permission to use the Tully-Murray floodplain hydrodynamic model developed by Connell Wagner and also acknowledge the supply of rainfall data from the BOM and river flow data from the DERM. We are grateful to Aaron Hawdon, Rex Keen and Paul Godfrey for assistance with field work and Rod Oliver and Ian Overton for their very helpful review comments on the draft manuscript. 


\section{REFERENCES}

Armour JD, Hateley LR, Pitt GL. 2007. Improved SedNet and Annex modelling of the Tully-Murray catchment. A report prepared for the Tully Water Quality Improvement Plan. Department of Natural Resources and Water, Queensland Government, Mareeba: Australia; 24.

Arthington AH, Balcombe SR. 2011. Extreme hydrologic variability and the boom and bust ecology of fish in arid-zone floodplain rivers: a case study with implications for environmental flows, conservation and management. Ecohydrology (2011): DOI: 10.1002/eco.221.

Balcombe SR, Arthington AH. 2009. Temporal changes in fish abundance in response to hydrological variability in a dryland floodplain river. Marine and Freshwater Research 60, 146-159.

Bayley PB. 1991. The flood pulse advantage and the restoration of river-floodplain systems. Regulated Rivers: Research \& Management 6: 75-86. DOI: 10.1002/rrr.3450060203.

Bayley PB. 1995. Understanding large river-floodplain ecosystems. BioScience 45: 153-158.

Beighley RE, Eggert K, Dunne T, He Y, Gummadi V. 2009. Simulating hydrologic and hydraulic processes throughout the Amazon River Basin. Hydrological Processes 23(8): 1221-1235. DOI:10.1002/hyp.7252.

BMT WBM 2008. Cardwell Inundation Study, Final Report. Department of Transport and Regional Services, Queensland Government: Brisbane; 153.

Bunn SE, Arthington AH. 2002. Basic principles and consequences of altered hydrological regimes for aquatic biodiversity. Environmental Management 30: 492-507.

Bunn SE, Thoms MC, Hamilton SK, Capon SJ. 2006. Flow variability in dryland rivers: boom, bust and the bits in between. River Research and Applications 22, 179-186.

Burrows DW. 1999. Review of Environmental Factors: Tully-Hull Road, Australian Centre for Tropical Freshwater Research, Report No. 99/26: Townsville; 9.

Cannon MG, Smith CD, Murtha GG. 1992. Soils of the Cardwell-Tully area, North Queensland, Divisional Report No 115, CSIRO Land and Water, Australia; 141.

Chormanski J, Swiatek DM, Michalowski R. 2009. A hydrodynamic model coupled with GIS for flood characteristics analysis in the Biebrza riparian wetland. Oceanological and Hydrobiological Studies 38: 65-73.

Chow VT. 1959. Open Channel Hydraulics. McGraw-Hill International Edition: Singapore; 680

Connell Wagner 2006. Tully-Murray Rivers Flood Study Calibration Phase Report, Department of Main Roads, Queensland Government: Brisbane; 17

DHI 2008a. MIKE 21 Flow Model: Scientific Documentation, DHI: Denmark; 60.

DHI 2008b. NAM technical reference and model documentation. MIKE by DHI (Danish Hydraulic Institute): Denmark; 96.

DHI 2008c. A modelling system for rivers and channels, Reference Manual, DHI: Denmark; 193. 
Durrant JM, Bowman S. 2004. Estimation of Rare Design Rainfalls for Western Australia: Application of the CRC-FORGE Method. Surface Water Hydrology Report No. HY17, Department of Environment, Government of Western Australia; 120.

EPA 1999. State of the Environment Queensland 1999. Environmental Protection Agency, Queensland Government: Brisbane, ISBN 0724282343.

EPA 2005. Wetland mapping and classification methodology -A method to provide baseline mapping and classification for wetlands in Queensland. Environmental Protection Agency, Queensland Government: Brisbane; 45.

Frazier P, Page K, Louis J, Briggs S, Robertson AI. 2003. Relating wetland inundation to river flow using Landsat TM data. International Journal of Remote Sensing 24, 3755-3770.

Frazier P, Page K. 2006. The effect of river regulation on floodplain wetland inundation, Murrumbidgee River, Australia. Marine and Freshwater Research 57: 133-141.

Gallardo B, Gascon S, Gonzalez-Sanchis M, Cabezas A, Comın FA. 2009. Modelling the response of floodplain aquatic assemblages across the lateral hydrological connectivity gradient. Marine and Freshwater Research 60, 924-935.

Ganf GG, White SD, Oliver RL. 2010. Allocating water to the wetlands of the Murray Valley to maximise aquatic plant species diversity. In Ecosystem Response Modelling in the MurrayDarling Basin, Saintilan N, Overton IC (eds). CSIRO Publishing: Canberra; 279-299.

Garcia R, Kahawita RA. 1986. Numerical solution of the St. Venant equations with the MacCormack finite difference scheme. International Journal of Numerical Methods in Fluids 6: 259-274.

Gopal B, Junk WJ. 2000. Biodiversity in wetlands: an introduction. In Biodiversity in Wetlands: Assessment, Function and Conservation, Gopal B, Junk WJ, Davis JA (eds), Vol. 1, Backhuys Publication: Leiden; 1-10.

Heiler G, Hein T, Schiemer F, Bornette G. 1995. Hydrological connectivity and flood pulses as the central aspects for the integrity of a river-floodplain system, Regulated Rivers: Research and Management 11: 351-361. DOI: 10.1002/rrr.3450060203.

Hess LL, Melack JM, Novo EM, Barbosa C, Gastil M. 2003. Dual-season mapping of wetland inundation and vegetation for the central Amazon basin, Remote Sensing of Environment 87: $404-428$.

Johnson AKL, Ebert SP, Murray AE. 1997. Spatial and temporal distribution of wetland and riparian zones and opportunities for their management in catchments adjacent to the Great Barrier Reef Marine Park. In Proceedings GBRMPA Cross-Sectoral Workshop on Wetlands and Water Quality. GBR Marine Park Authority: Townsville; 82-101.

Junk WJ, Bayley PB, Sparks RE. 1989. The flood pulse concept in river-floodplain systems. Canadian Special Publication of Fisheries and Aquatic Sciences 106: 110-127. 
Karim F, Wallace JS, Henderson A, Wilkinson S. 2008. Assessment of sediment and nutrient across Tully-Murray floodplain using SedNet and ANNEX models. CSIRO Land and Water Report 59/08: Canberra; 18p.

Karim F, Wallace J, Kinsey-Henderson A, Hawdon A, Keen A, Arthington A, Godfrey P and Pearson R. 2011. Wetlands and Floodplains: connectivity and hydro-ecological function, Part IIQuantification of overbank and channelized wetland connectivity in the Tully-Murray floodplain, Reef and Rainforest Research Centre Ltd.: Cairns; 45p.

Lasne E, Lek S, Laffaille P. 2007. Patterns in fish assemblages in the Loira floodplain: The role of hydrological connectivity and implications for conservation. Biological Conservation 139: 258268.

Leigh C, Sheldon F. 2009. Hydrological connectivity drives patterns of macroinvertebrate biodiversity in floodplain rivers of the Australian wet/dry tropics. Freshwater Biology 54: 549-571.

Leigh C, Sheldon F, Kingsford RT, Arthington AH. 2010. Sequential floods drive 'booms' and wetland persistence in dryland rivers: a synthesis. Marine and Freshwater Research 61(8): 896908.

McGuckin J. 2000. Management implications of fish movement and migration - the role of the consultant: In Fish Movement and Mitigation, Proc. Australian Society for Fish Biology Workshop, Hancock DA, Smith DC, Koehn JD (eds). Australian Society for Fish Biology: Sydney; 261-263.

Middleton BA. 2002. The flood pulse concept in wetland restoration: In Flood Pulsing in Wetlands: Restoring the Natural Hydrological Balance, Middleton BA (eds). John Wiley and Sons: New York; 1-10.

Nicholas AP, Mitchell CA. 2003. Numerical simulation of overbank processes in topographically complex floodplain environments. Hydrological Processes, 17: 727-746.

Overton IC. 2005. Modelling floodplain inundation on a regulated river: Integrating GIS, remote sensing and hydrological models. River Research and Applications 21, 991-1001.

Paterson AW, Whitfield AK. 2000. Do shallow-water habitats function as refugia for juvenile fishes? Estuarine, Coastal and Shelf Science 51: 359-364.

Peake P, Fitzsimons J, Frood D, Mitchell M, Withers N, White M, Webster R. 2011. A new approach to determining environmental flow requirements: Sustaining the natural values of floodplains of the southern Murray-Darling Basin. Ecological Management \& Restoration 12: 128-137.

Pearson RG, Arthington AH, Godfrey PC, 2010. Ecosystem health of wetlands of the Great Barrier Reef catchment: Tully-Murray floodplain case study. Final Report, Marine and Tropical Science Research Facility Project 3.7.3, Reef and Rainforest Research Centre Ltd: Cairns; 120p

Pilgrim DH, Kennedy MR, Rowbottom IA, Cordery I, Canterford RP, Turner LH. 2001. Temporal patterns of rainfall bursts. Australian Rainfall and Runoff: A Guide to flood Estimation. Volume 1, Book II, Institution of Engineers Australia: Canberra (in CD ROM). 
Pitt G, Grounds S, van den Berg D, Denham R. 2007. Mapping Land Use - Land Use Change Mapping from 1999 to 2004 for the Tully River Catchment, Department of Environment and Resource Management; Brisbane: 21p.

Pringle CM. 2001. Hydrologic connectivity and the management of biological reserves: A global perspective. Ecological Applications 11: 981-998.

Rebecca EL, Webster IT, Fairweather PG, Young WJ. 2011. Linking water-resource models to ecosystem-response models to guide water-resource planning - an example from the MurrayDarling Basin, Australia. Marine and Freshwater Research 62: 279-289.

Rosenfield S, Hatfield T. 2006. Information needs for assessing critical habitat of freshwater fish. Canadian Journal of Fisheries and Aquatic Sciences 63: 683-698.

Rungo M, Olesen KW. 2003. Combined 1- and 2- Dimensional Flood Modelling. $4^{\text {th }}$ Iranian Hydraulic Conference, 21-23 October, Shiraz, Iran

Sanger AC. 2000. Fisheries management implications of barriers to movement and migration by fish in New South Wales: In Fish Movement and Mitigation, Proc. Australian Society for Fish Biology Workshop, Hancock DA, Smith DC and Koehn JD (eds). Australian Society for Fish Biology: Sydney; 246-251.

Sattler P, Williams R (eds). 1999. The Conservation Status of Queensland's Bioregional Ecosystems. Environmental Protection Agency; Brisbane.

Schumann G, Bates PD, Horritt MS, Matgen P, Pappenberger F. 2009. Progress in integration of remote sensing-derived flood extent and stage data and hydraulic models, Reviews of Geophysics, 47: RG4001.

Shaikh M, Green D, Cross H. 2001. A remote sensing approach to determine environmental flows for wetlands of the Lower Darling River, New South Wales, Australia. International Journal of Remote Sensing 22, 1737-1751.

Smith DM, Brough DM. 2006. Modelling the land surface: A report on the creation of Digital Elevation Models for high priority regions of Queensland. Dept. of Natural Resources, Mines and Water. Report No. QNRM06196: Brisbane; 29p.

Sparks RE. 1995. Need for ecosystem management of large rivers and their floodplains. BioScience 45: $168-182$.

Stelling GS, Verwey A. 2005. Numerical flood simulation. In Encyclopedia of Hydrological Sciences. Chaper 16, Anderson MG (eds): 1-14

Subramanya K. 1994. Engineering hydrology, Second Edition, Tata McGraw-Hill Publishing Company Limited: New Delhi; 392p.

Swales S, Storey AW, Roderick ID, Figa BS. 1999. Fishes of floodplain habitats of the Fly River system, Papua New Guinea, and changes associated with El Nino droughts and algal blooms. Env Biology of Fishes 54 (4) 389-404. 
Thoms MC. 2003. Floodplain-river ecosystems: lateral connections and the implications of human interference. Geomorphology 56: 335-349

Tockner K, Malard F, Ward JV. 2000. An extension of the flood pulse concept. Hydrological Processes 14: 2861-2883.

Tockner K, Bunn SE, Quinn G, Naiman R, Stanford JA, Gordon C. 2008. Floodplains: Critically threatened ecosystems. In Aquatic Ecosystems, Polunin NC (eds). Cambridge University Press: Cambridge, UK; 45-61.

Tockner KA, Lorang MS, Stanford JA. 2010. River flood plains are model ecosystems to test general hydrogeomorphic and ecological concepts. River Research and Applications 26, 76-86.

Townsend PA, Walsh SJ. 1998. Modeling floodplain inundation using an integrated GIS with radar and optical remote sensing. Geomorphology 21, 295-312.

Tuteja NK, Shaikh M, 2009. Hydraulic modelling of the spatio-temporal flood inundation patterns of the Koondrook Perricoota forest wetlands- the living Murray. In Proc. $18^{\text {th }}$ World IMACS, MODSIM Congress: Cairns; 4248-4254.

Veitch V, Sawynok B. 2004. Freshwater Wetlands and Fish. Sunfish Queensland Inc. Report No. SQ200401: Brisbane; 136.

Wallace JS, Stewart LS, Hawdon A, Keen R. 2008. The impact of floods on sediment and nutrient fluxes from the Tully-Murray catchments to the GBR lagoon. Report to TERRAIN and MTSRF for input to the Water Quality Improvement Planning process. CSIRO Science Report. Y/07: Canberra; 56p.

Wallace J, Stewart L, Hawdon A, Keen R, Karim F, Kemei J. 2009. Flood water quality and marine sediment and nutrient loads from the Tully and Murray catchments in north Queensland, Australia. Marine and Freshwater Research 60, 1123-1131.

Welcomme RL, Bene C, Brown CA, Arthington A, Dugan P, King JM, Sugunan V. 2006. Predicting the water requirements of river fisheries. In Wetlands and Natural Resource Management, Verhoeven JTA, Beltman B, Bobbink R, Whigham DF (eds). Springer-Verlag: Berlin; 123-154.

Winemiller KO. 1996. Dynamic Diversity in Fish Assemblages of Tropical Rivers. In Long-term Studies of Vertebrate Communities, Cody ML, Smallwood JA (eds). Academic Press, Orlando: Florida; 99-134. 
Table I. Calibrated NAM model parameters for the Cochable Creek and Murray River subcatchments. The parameters are $U_{\max }$ (maximum water content in surface storage), $L_{\max }$ (maximum water content in root zone storage), $C Q_{O F}$ (overland flow runoff coefficient), $C K_{I F}$ (time constant for routing inter flow), $C K_{O F}$ (time constant for routing overland flow), $T_{O F}$ (root zone threshold value for overland flow), $T_{I F}$ (root zone threshold value for interflow), $T_{G}$ (root zone threshold value for groundwater recharge) and $C K_{B F}$ (time constant for routing base flow)

\begin{tabular}{lccccccccc}
\hline Catchment & $\begin{array}{c}U_{\max } \\
(\mathrm{mm})\end{array}$ & $\begin{array}{c}L_{\max } \\
(\mathrm{mm})\end{array}$ & $C Q_{O F}$ & $\begin{array}{c}C K_{I F} \\
\text { (hours) }\end{array}$ & $\begin{array}{c}C K_{O F} \\
\text { (hours) }\end{array}$ & $T_{O F}$ & $T_{I F}$ & $T_{G}$ & $\begin{array}{c}C K_{B F} \\
\text { (hours) }\end{array}$ \\
\hline Coachable Creek & 6 & 14 & 0.85 & 500 & 48 & 0.05 & 0.10 & 0.38 & 2000 \\
Murray River & 16 & 24 & 0.12 & 351 & 10 & 0.15 & 0.21 & 0.80 & 2982 \\
\hline
\end{tabular}


Table II. Statistical parameter discrepancy between observed and computed discharges for rainfall-runoff model calibration

\begin{tabular}{lcccc}
\hline Gauge location & No. of data & $\begin{array}{c}R M S E \\
\left(\mathrm{~m}^{3} / \mathrm{s}\right)\end{array}$ & $\begin{array}{c}\text { Correlation } \\
\text { coefficient }\end{array}$ & $\begin{array}{c}R E \\
(\%)\end{array}$ \\
\hline Powerline & 532 & 2.98 & 0.96 & 0.50 \\
Upper Murray & 289 & 4.75 & 0.81 & 0.09 \\
\hline$R M S E=$ Root mean square error, $R E=$ Relative error & &
\end{tabular}

$R M S E=$ Root mean square error, $R E=$ Relative error 
Table III. Calibrated Manning's roughness coefficient $(n)$ for different land uses and a comparison with previous hydrodynamic study

\begin{tabular}{lccc}
\hline Land use & Investigated & Calibrated & $\begin{array}{c}\text { Connell } \\
\text { Wagner (2006) }\end{array}$ \\
\hline Sugarcane & $0.10-0.60$ & 0.20 & 0.09 \\
Banana & $0.08-0.20$ & 0.10 & 0.10 \\
Grazing & $0.08-0.20$ & 0.09 & 0.12 \\
Cereal & 0.10 & 0.10 & 0.10 \\
Urban & $0.10-0.30$ & 0.12 & - \\
River & 0.025 & 0.025 & 0.025 \\
Creek & 0.05 & 0.05 & 0.06 \\
Wetland & 0.04 & 0.04 & - \\
\hline
\end{tabular}


Table IV. Simulated floodplain inundation for floods with ARIs of 1, 20 and 50 years (Areas include water bodies such as rivers, creeks and wetlands)

\begin{tabular}{lccc}
\hline Flood magnitude & $\begin{array}{c}\text { Rainfall } \\
\text { volume }\end{array}$ & \multicolumn{2}{c}{ Inundated area } \\
\cline { 3 - 4 }$\left(\mathrm{km}^{3}\right)$ & $\left(\mathrm{km}^{2}\right)$ & $(\%)$ \\
\hline No floods & - & 60 & 7.2 \\
1 year ARI & 0.85 & 308 & 37.0 \\
20 year ARI & 1.39 & 429 & 51.6 \\
50 year ARI & 1.68 & 456 & 54.8 \\
\hline
\end{tabular}


Table V. Summary of connectivity of 10 floodplain wetlands with the Tully and Murray Rivers for floods with ARIs of 1, 20 and 50 years

\begin{tabular}{lcccccc}
\hline Name & \multicolumn{6}{c}{ Duration of connection (days) } \\
\cline { 2 - 7 } & \multicolumn{2}{c}{ ARI 1 year } & \multicolumn{2}{c}{ ARI 20 year } & \multicolumn{2}{c}{ ARI 50 year } \\
\cline { 2 - 7 } & Tully & Murray & Tully & Murray & Tully & Murray \\
\hline Boongaray & $1-2$ & $4-5$ & $3-4$ & $6-7$ & $3-4$ & $11-12$ \\
Bunta & $1-2$ & $2-3$ & $3-4$ & $4-5$ & $3-4$ & $7-8$ \\
Digman's & $1-2$ & $2-3$ & $3-4$ & $4-5$ & $3-4$ & $6-7$ \\
Hassall 1 & $1-2$ & $3-4$ & $3-4$ & $4-5$ & $3-4$ & $7-8$ \\
Hassall 2 & $1-2$ & $3-4$ & $3-4$ & $4-5$ & $3-4$ & $7-8$ \\
Kyambul & $1-2$ & $3-4$ & $3-4$ & $3-4$ & $3-4$ & $7-8$ \\
Lagoon Creek & 0 & 0 & $1-2$ & $1-2$ & $2-3$ & $2-3$ \\
Landcare & $1-2$ & $11-12$ & $3-4$ & $11-12$ & $3-4$ & $11-12$ \\
Selby's & $1-2$ & $4-5$ & $3-4$ & $5-6$ & $3-4$ & $11-12$ \\
Zamora's & $1-2$ & $3-4$ & $3-4$ & $4-5$ & $3-4$ & $8-9$ \\
\hline
\end{tabular}




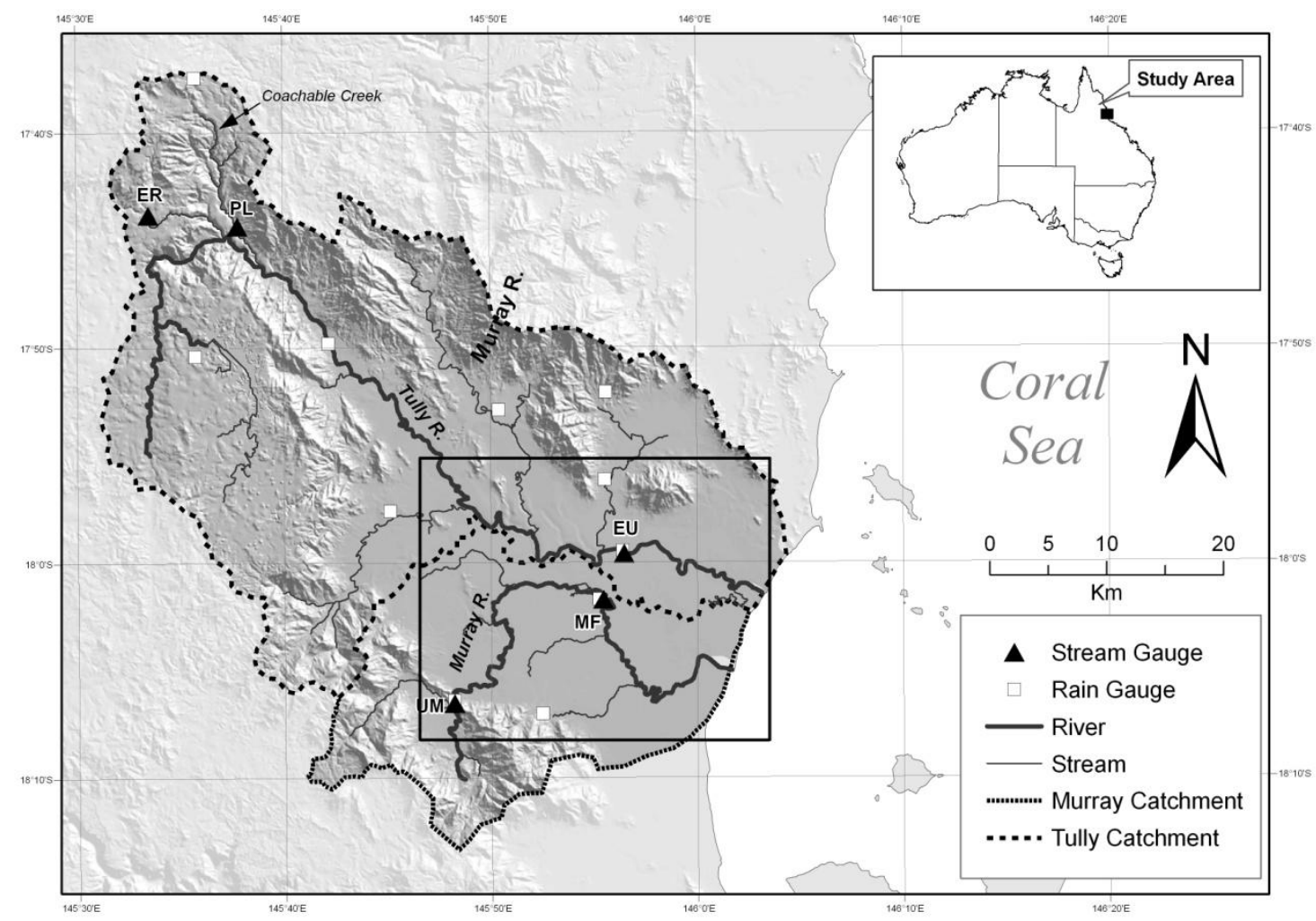

Figure 1. A schematic map of the Tully and Murray catchments showing the rivers and major creeks. The rectangle shows the $30 \mathrm{~km} \times 24 \mathrm{~km}$ area used in the MIKE 21 hydrodynamic model. Location of stream gauges in the upper catchment [ER: Ebony Road, PL: Powerline] and in the floodplain [UM: Upper Murray, MF: Murray Flats, ER: Euramo] are shown on the figure. 
(a)

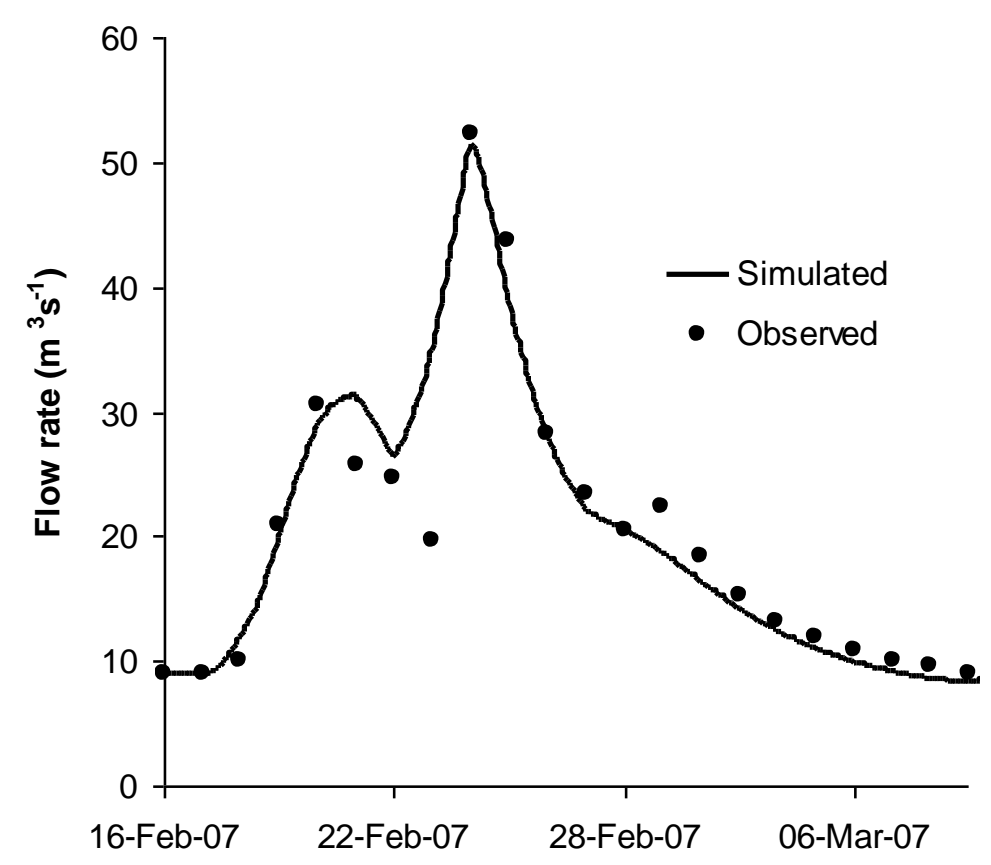

(b)

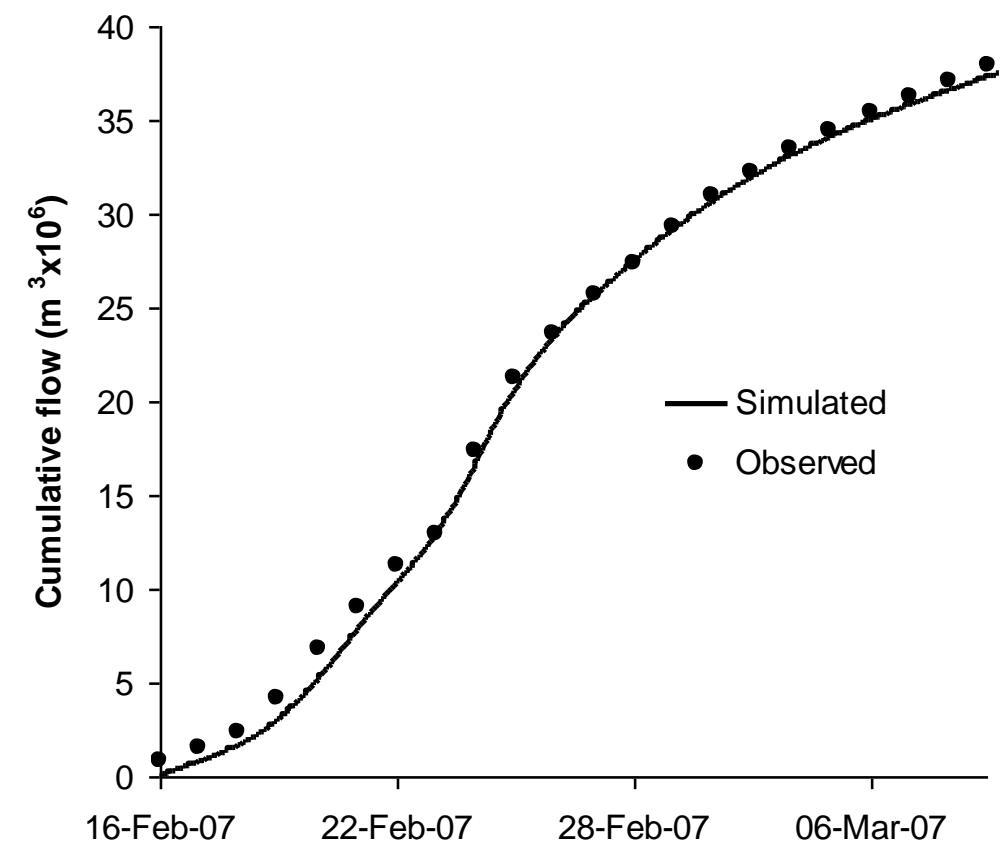

Figure 2. Comparison between simulated and observed (a) discharge and (b) cumulative flow at Powerline for the Coachable Creek sub-catchment for the flood event in February 2007 (gauge location is shown in Figure 1). 
(a)

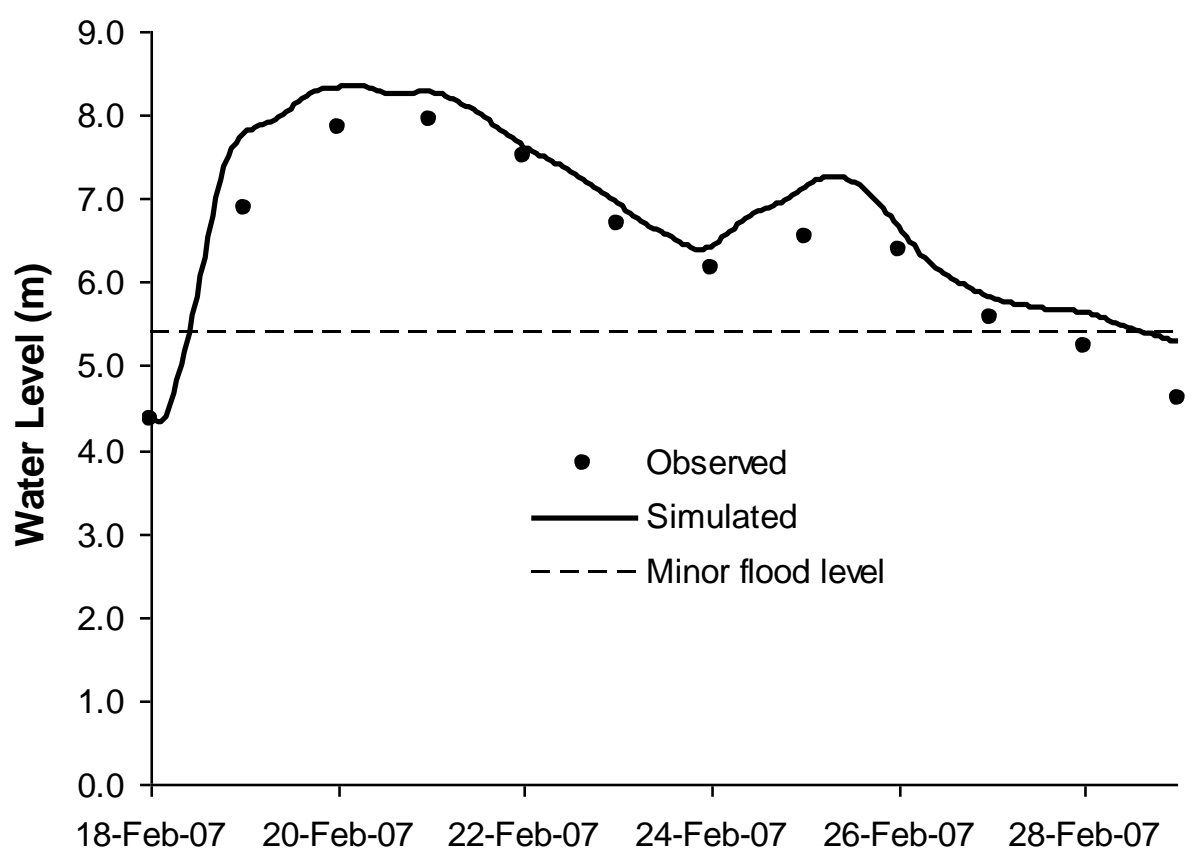

(b)

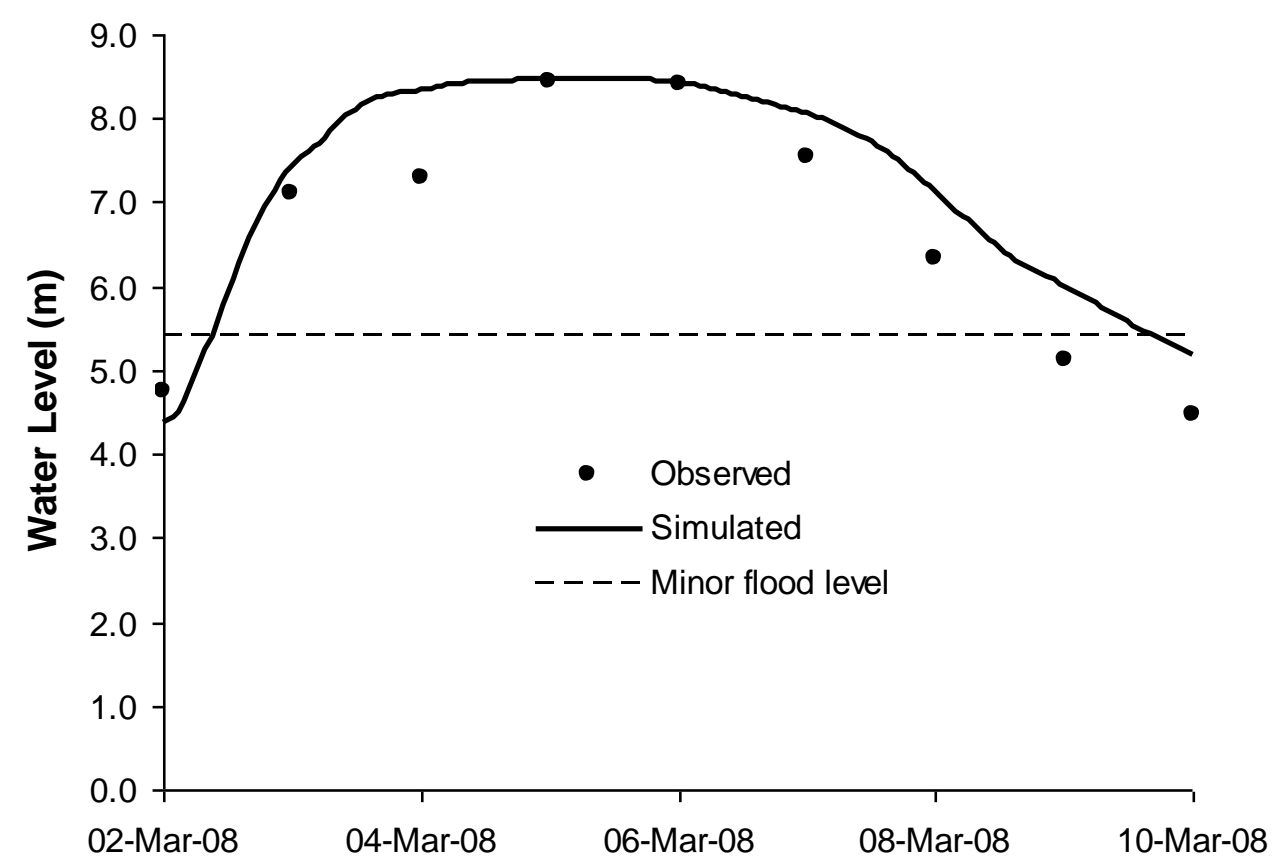

Figure 3. Comparison between computed and measured water levels at Euramo for (a) the 1 year ARI calibration event and (b) an independent 1.9 year ARI event. 


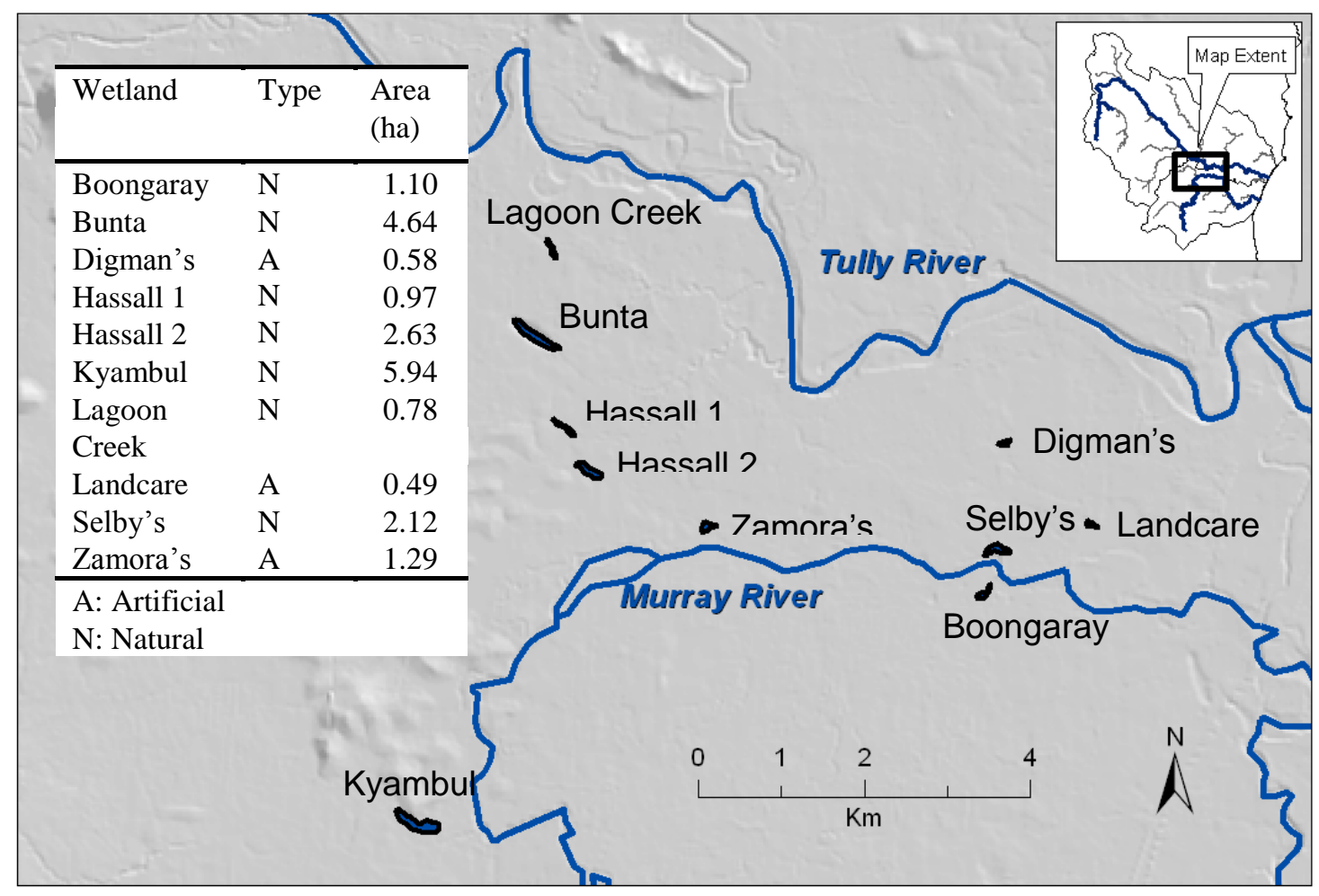

Figure 4. The Tully-Murray floodplain showing the size and locations of wetlands studied and their proximity to the Tully and Murray Rivers. Wetland types and surface area of individual wetlands are shown in the Table insert.

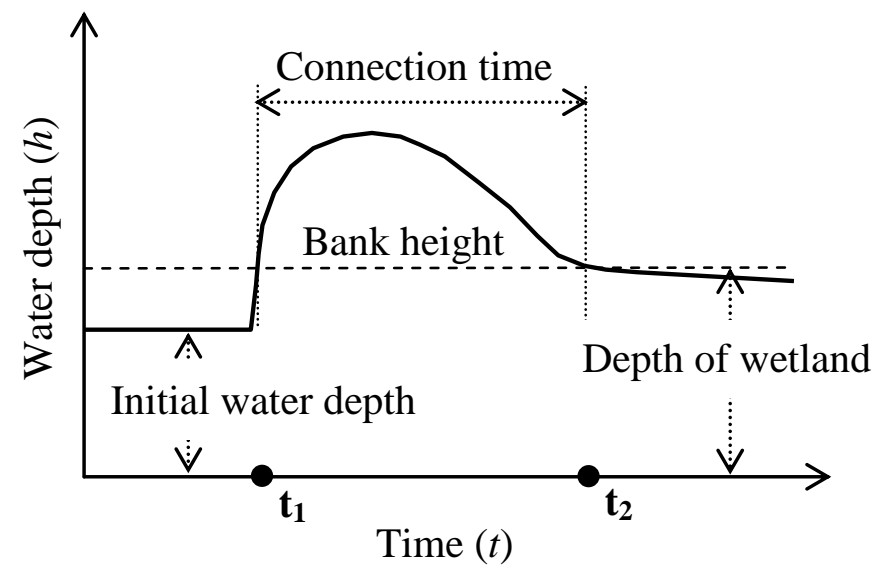

Figure 5. A schematic view of wetland connectivity based on water depth and wetland bank height. Connection to the surrounding water bodies starts at time $t_{1}$ and ends at $t_{2}$ when the depth of inundation falls below the wetland bank height. 


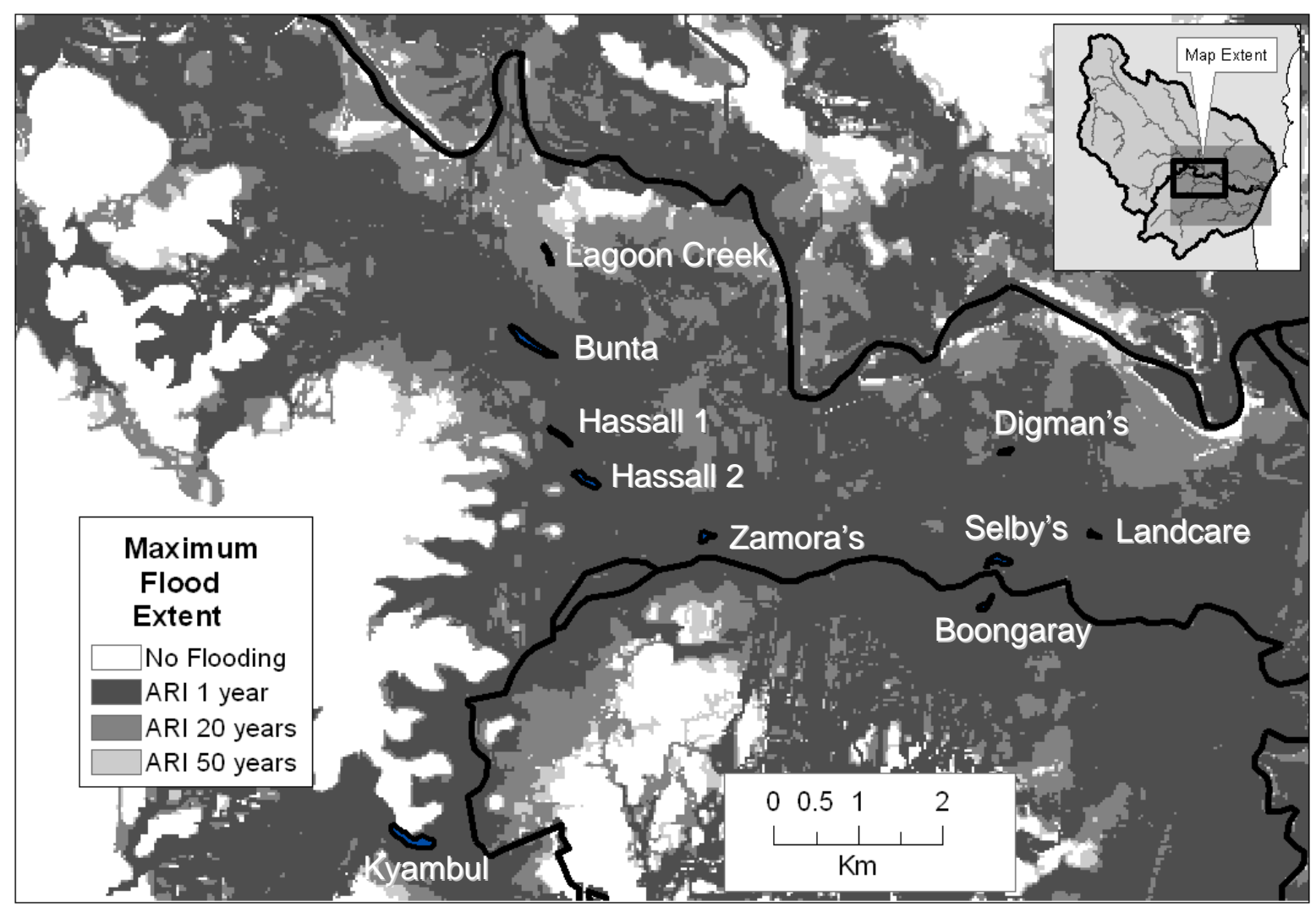

Figure 6. Areal extent of floodplain inundation for floods with magnitude of ARIs 1, 20 and 50 years. Inundation status of wetlands studied can be seen in the figure. 


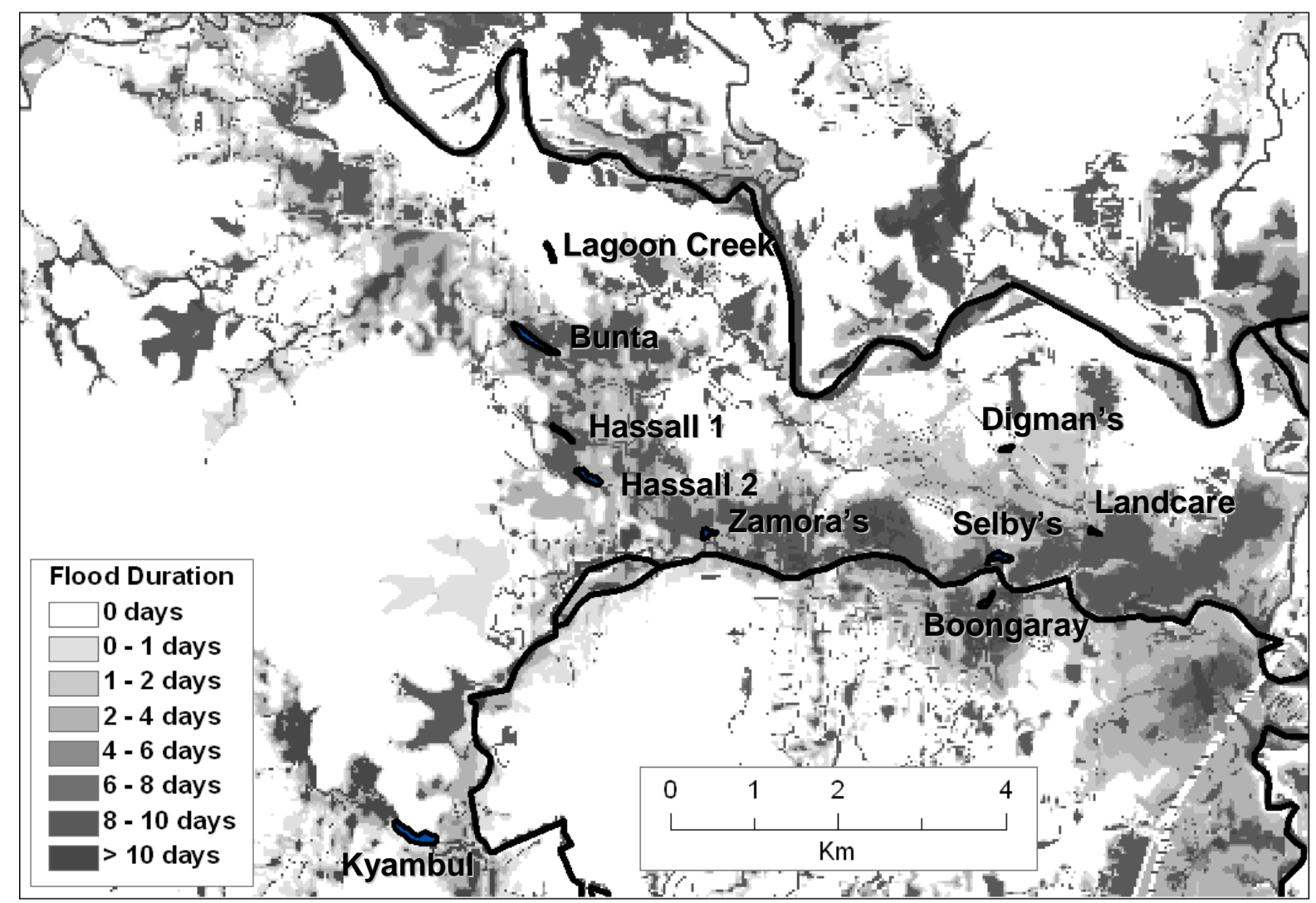

Figure 7. A typical example of the spatial variation in inundation duration across the floodplain for a flood having a return period of 1 year. 
(a)

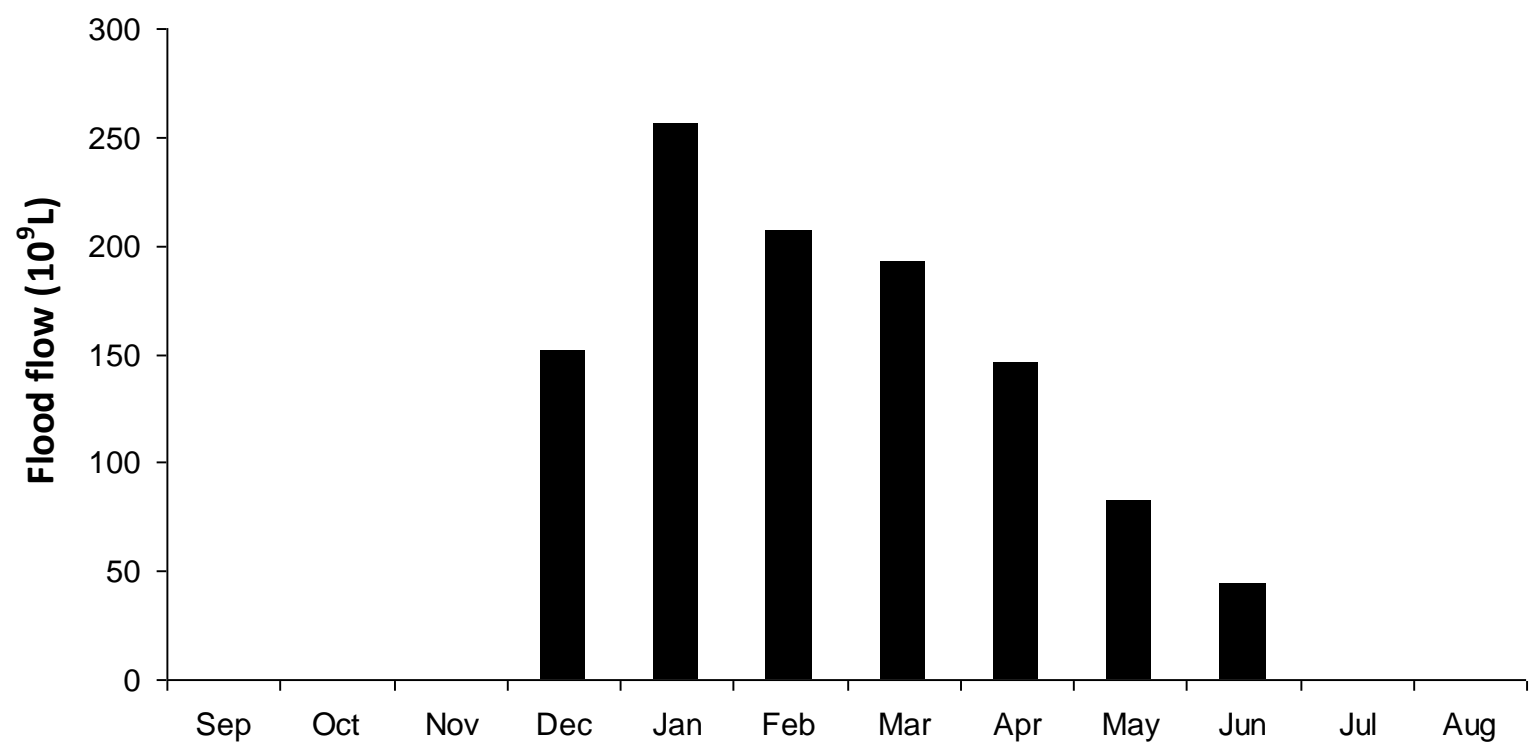

(b)

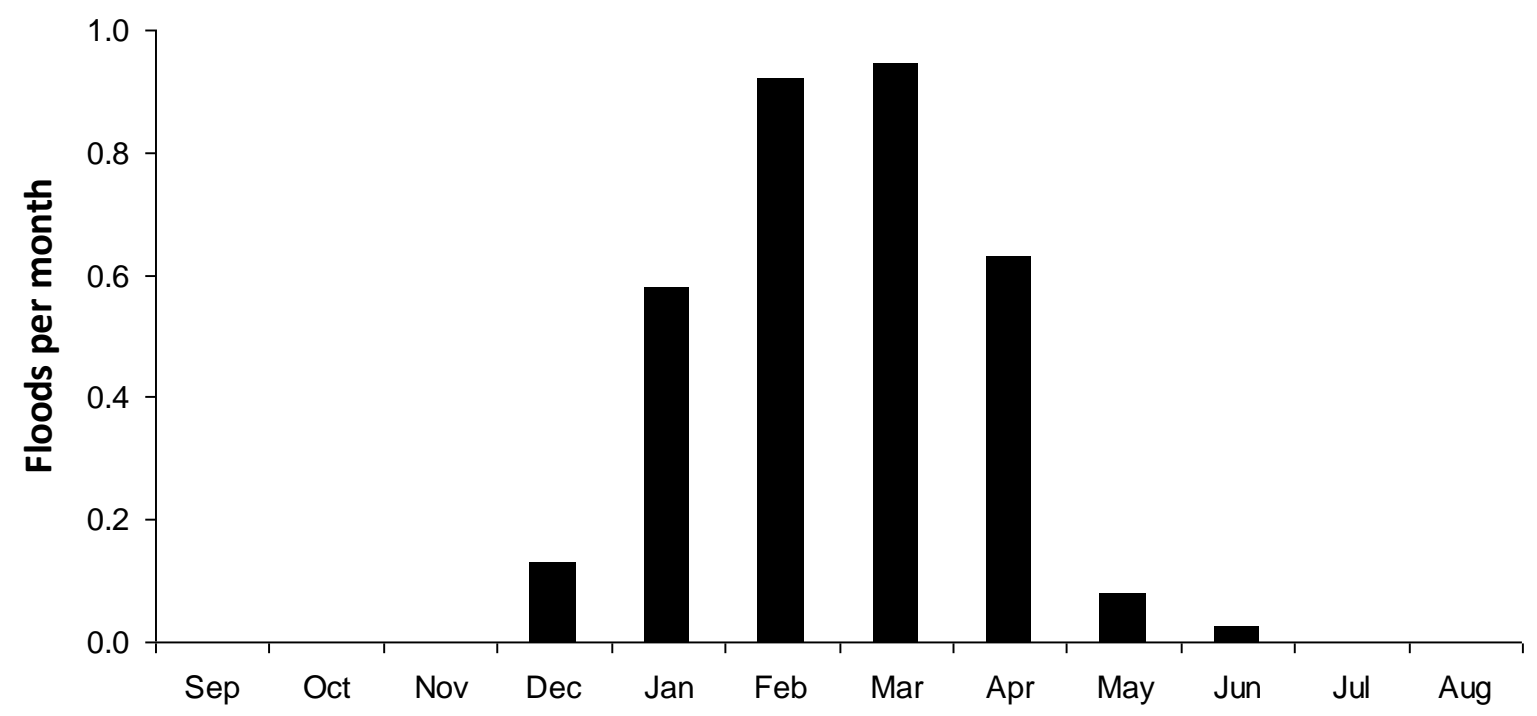

Figure 8. Seasonal variations in monthly average (a) flood flow and (b) number of floods based on records for the Euramo gauge and 38 years of record (1972 to 2009). 


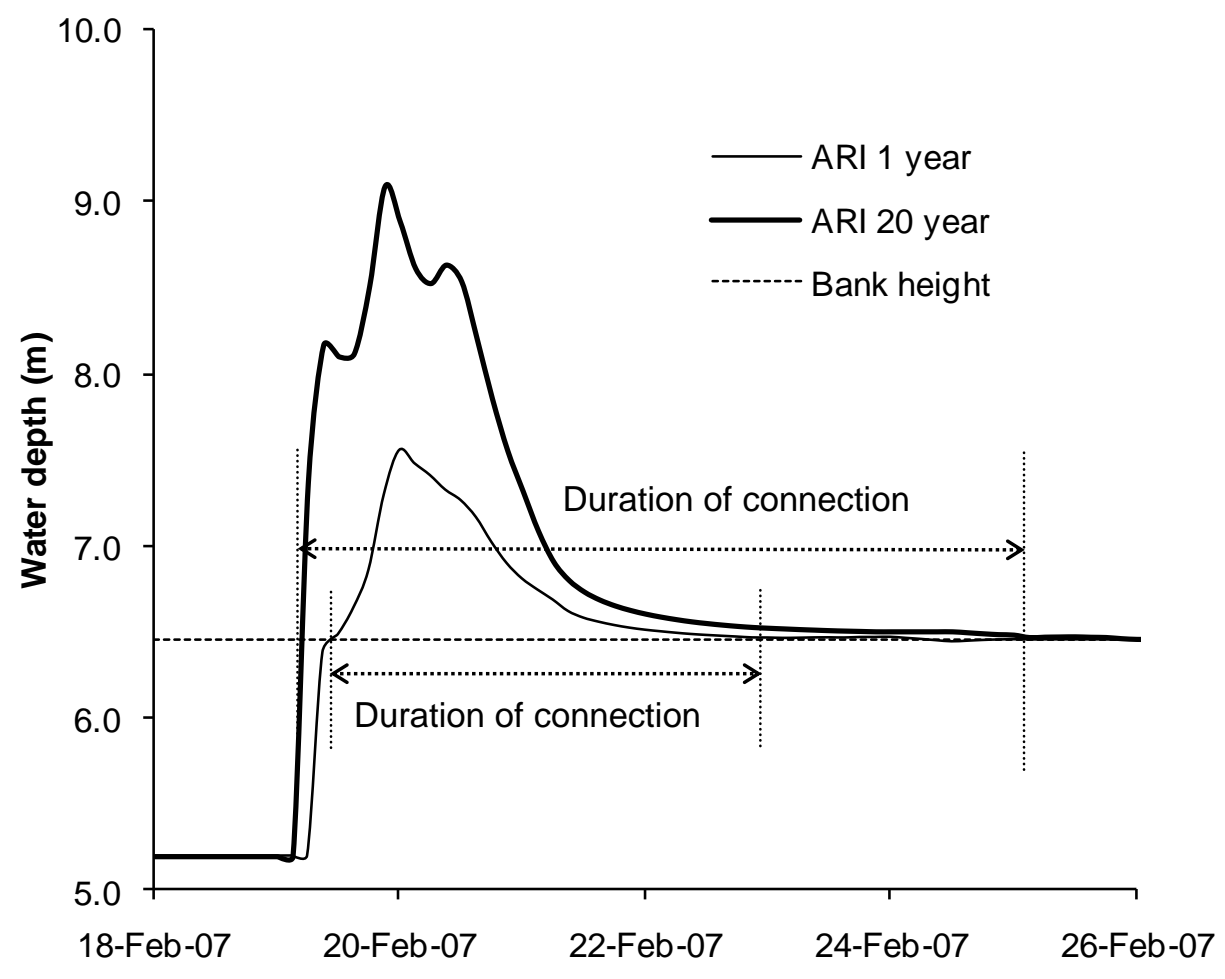

Figure 9. An illustration of overbank connectivity at Bunta wetland based on water depth information derived from the MIKE 21 hydrodynamic model. Two flood sizes are shown with ARIs of 1 and 20 years. 


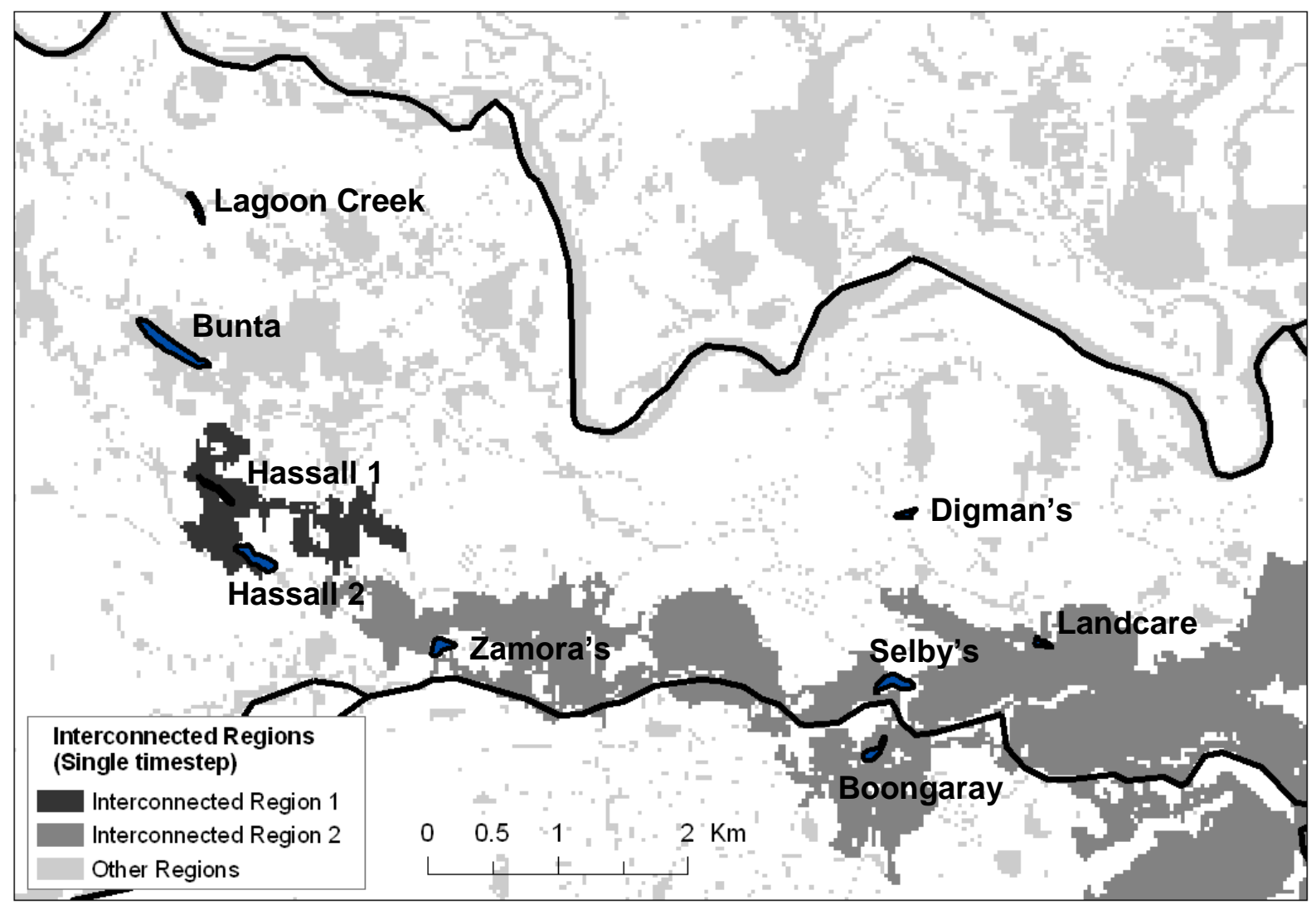

Figure 10. Connectivity analysis based on water depths derived from the MIKE 21 hydrodynamic model. The different shadings shows contiguous water bodies 106 hours after the start of a flood with an annual return period of 1 year. In this example the wetlands Zamora's, Selby's, Landcare and Boongaray are connected to the Murray River, whereas Hassall 1, Hassall 2, Digman's and Lagoon Creek are not. At this time none of the wetlands are connected to the Tully River. 
Connected to Tully River

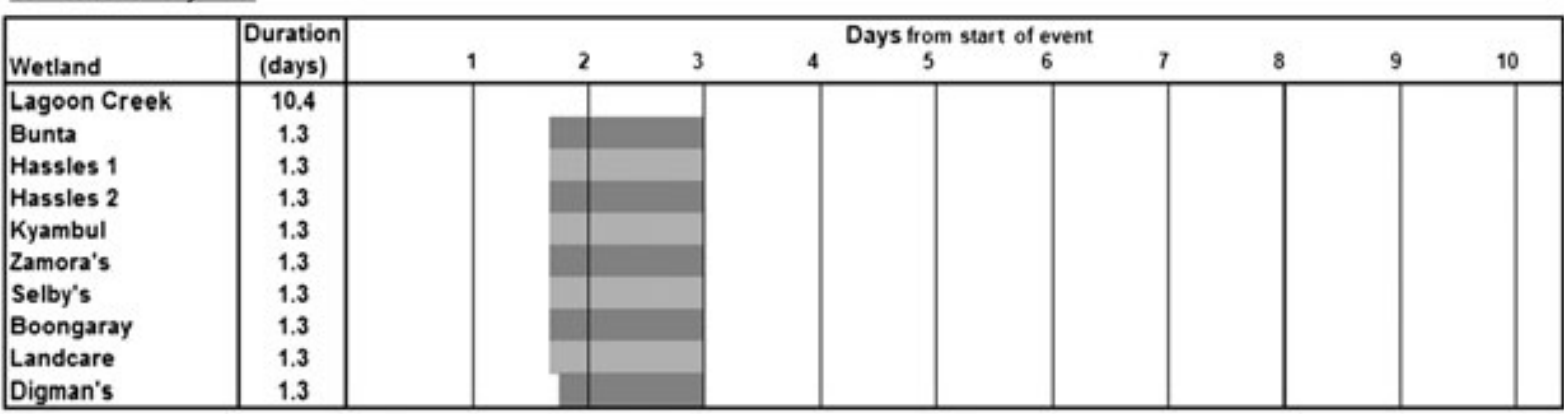

Connected to Murray River

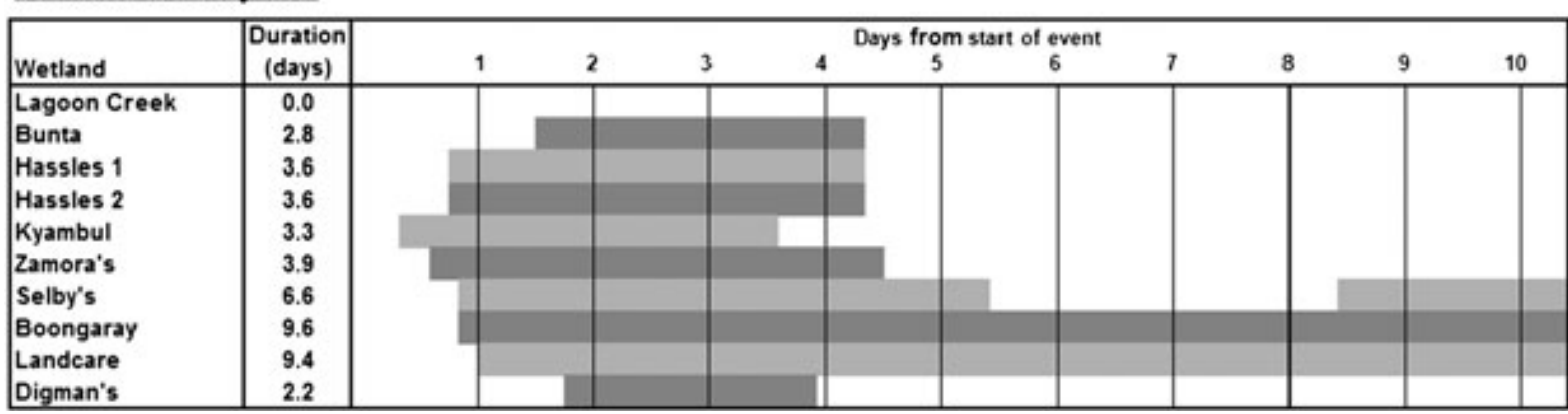

Figure 11. Summary of the timing and duration of connectivity of selected wetlands to the Tully and Murray Rivers for the flood event of February 2007.

Selby's wetland was reconnected to the Murray because of second peak of the flood

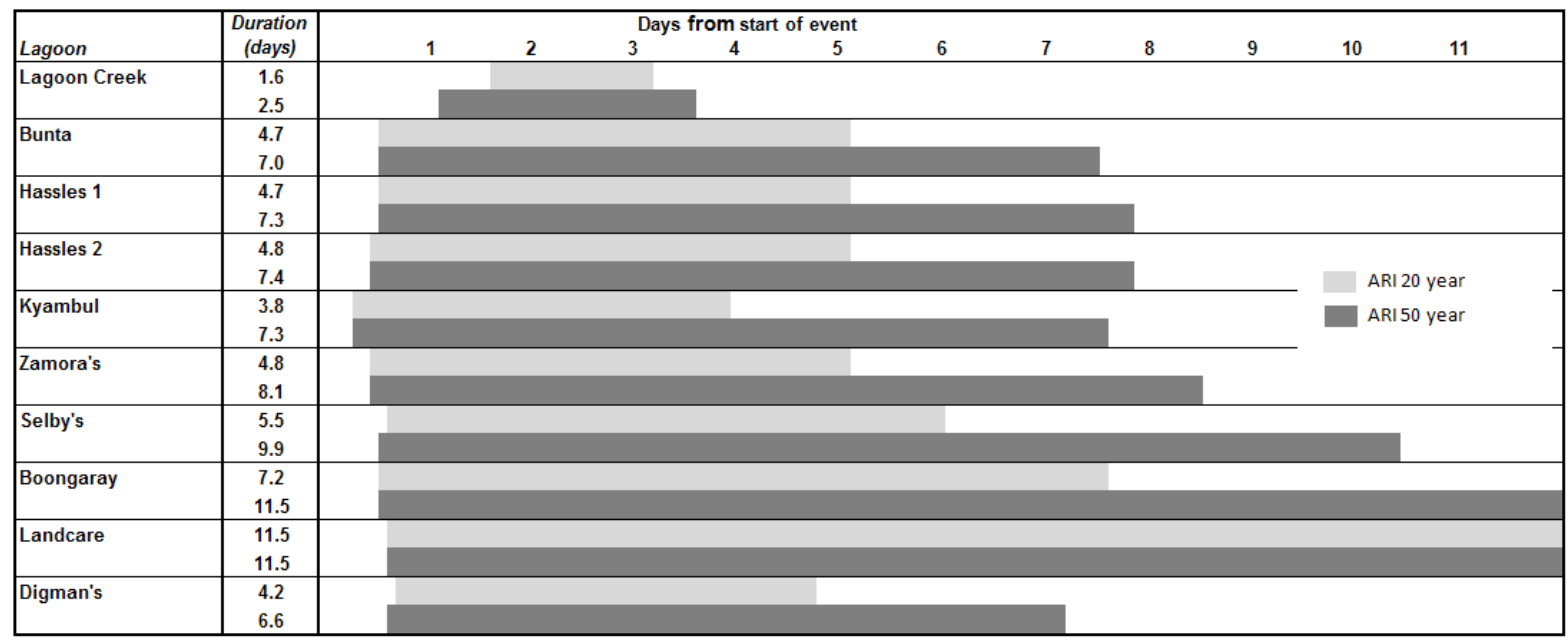

Figure 12. Effect of flood magnitude on timing and duration of connectivity of wetlands to the Murray River for floods with ARIs of 20 and 50 years. 